\title{
Evidence for a complex regulatory array in the first intron of the human adenosine deaminase gene
}

\author{
Bruce Aronow, David Lattier, Richard Silbiger, Mary Dusing, John Hutton, Gary Jones, Jeff Stock, \\ John McNeish, Steven Potter, David Witte, ${ }^{1}$ and Dan Wiginton \\ Divisions of Basic Science Research and 'Pathology, Children's Hospital Medical Center and Department of Pediatrics, \\ University of Cincinnati, Cincinnati, Ohio 45229 USA
}

\begin{abstract}
Adenosine deaminase (ADA) is expressed ubiquitously by diverse mammalian cells and tissues but at levels that vary according to tissue and species. In humans, the thymus exhibits levels of the enzyme up to 100 -fold higher than most other tissues. Using transgenic mice, we identified human ADA gene regulatory domains. Up to 3.7 kb of 5'-flanking and first exon DNA from the human ADA gene failed to promote the expression of a chloramphenicol acetyl transferase (CAT) reporter gene in an efficient, reproducible, or tissue-appropriate manner in transgenic mice. However, when $12.8 \mathrm{~kb}$ of DNA from the first intron of the human ADA gene was placed 3' of CAT-coding and -processing sequences, transgenic mice reproducibly expressed CAT activity in most tissues, with profoundly high levels in the thymus. DNase I hypersensitivity studies demonstrated that among transgenic mouse tissues, human thymus, and a variety of human cell lines, a region of the intron 4-10 $\mathbf{k b}$ downstream of the first exon exhibited an array of hypersensitive sites that varied according to tissue and cell type. Deletion of this region from the gene construction eliminated high-level expression in transgenic mice. In transfection-transient expression assays, the 12.8 -kb intron fragment exhibited enhancer activity in several cell types. A 1.3-kb fragment encompassing two of the hypersensitive sites exhibited some of these activities. The results of these studies suggest that the diverse pattern of human ADA gene expression is determined, in part, by a cluster of cis-regulatory elements contained within its large first intron.
\end{abstract}

[Key Words: Adenosine deaminase; transgenic mice; thymic gene expression; intronic enhancer; DNase Ihypersensitivity; in situ hybridization]

Received May 12, 1989; revised version accepted July 7, 1989

Adenosine deaminase (ADA), a 41,000 dalton polypeptide, is essential for normal development of the immune system (for review, see Carrera and Carson 1987). Children with a deficiency of the enzyme lack cellular and humoral immunity (Giblett et al. 1972). In all mammalian species that have been studied, high levels of the enzyme are detected in cortical thymocytes (Chechik et al. 1981, 1983; Ma et al. 1982), a population of cells undetectable in children with ADA deficiency (Borzy et al. 1979; Gosseye et al. 1983). In humans and mice, the expression of ADA declines as a function of lymphocyte maturation, and ADA specific activities of peripheral blood lymphocytes, spleen, and lymph node are considerably less than that of thymus (Adams and Harkness 1976; Van der Weyden and Kelley 1976; Hirschhorn et al. 1978; Chechik et al. 1981; Kizaki et al. 1983). Newborn mice exhibit a low level of ADA activity in the gastrointestinal tract, but at 1-2 weeks of age, a 100- to 1000-fold increase in ADA activity occurs (Lee 1973). In humans, low levels of the enzyme $11-5 \%$ that of the thymus) are found in most other tissues, such as liver, lung, heart, kidney, and most regions of the brain
(Adams and Harkness 1976; Van der Weyden and Kelley 1976; Hirschhorn et al. 1978). Thus, there is a general pattern of low-level ADA expression in diverse tissues and, in addition, a high level of expression in some tissues subject to developmental differentiation. Species-specific differences in ADA expression have also been observed (Brady and O'Donovan 1965), and as detailed in Results, some of the tissues that exhibit high-level ADA expression differ dramatically between mice and humans.

Human ADA is encoded by a single gene (Tischfield et al. 1974) of 12 exons with a very GC-rich promoter lacking consensus CAAT and TATAA sequences, though containing at least five consensus Spl-binding motifs (Valerio et al. 1985; Wiginton et al. 1986). A single major cap site is used in T-lymphoid cells (Valerio et al. 1985; Akeson et al. 1987), and a fragment of DNA that extends $135 \mathrm{bp}, 5^{\prime}$ of the cap site functions as a promoter in transient expression assays in a variety of cell types (Valerio et al. 1985, this study). In this laboratory, Wiginton et al. (1986) has determined the sequence of 32 $\mathrm{kb}$ of transcribed and $3.9 \mathrm{~kb}$ of $5^{\prime}$-flanking DNA encom- 
passing the human gene, and Lattier et al. (1989) have recently shown that at least some of the variations in expression of the enzyme are the result of variations in transcription of the gene. Human T-, B-, and fibroblastoid cell lines differing by up to 60 -fold in ADA-specific activity exhibited parallel variations in mRNA levels and in nuclear transcription chain-elongation assays. To begin to determine the molecular basis for the cell-type and tissue-specific expression pattern of the human $\mathrm{ADA}$ gene, transgenic mice were made with a series of gene constructions in which the synthesis of chloramphenicol acetyltransferase (CAT) was directed by DNA from the human ADA gene. A high-level and reproducible pattern of expression could be obtained only in the transgenic mice when DNA sequences from a portion of the first intron were included in the constructions. Critical intronic segments were associated with a cluster of DNase I-hypersensitive sites that varied in an intricate, yet consistent, fashion among human thymus, human cell lines, and transgenic mouse tissues. Using transfection-transient expression assays, we were also able to demonstrate that a strong T-cell-specific enhancer was present within the region.

\section{Results}

\section{Constructions}

A series of pADA CAT vectors, from which transgenes were derived, were made first by inserting successively greater lengths of DNA from the $5^{\prime}$ sequences of the human ADA gene into the promoterless vector pSVOCAT (Gorman et al. 1982). All constructions contained core promoter sequences and 98 bp of $5^{\prime}$-untranslated first exon DNA from the human gene. Other plasmids were constructed that contained both 5 '-flanking DNA and first intron DNA from the human gene. The smallest vector, pADA CAT 0.2 , contained a 232 -bp fragment from the human gene, inserted in the appropriate orientation into the HindIII site of pSV0-CAT. This small fragment exhibits promoter activity in transfection-transient expression assays (this study; Valerio et al. 1985). Two other constructions extended the core promoter element further $5^{\prime}$ with 2.2 and $4.0 \mathrm{~kb}$ of $5^{\prime}$ flanking DNA from the human ADA gene. Because the human ADA gene contains 12 exons that span $32 \mathrm{~kb}$ and the first intron itself is $15.2 \mathrm{~kb}$ (Wiginton et al. 1986), we sought to test for the presence of cis-acting signals in the first intron. To do this, a fourth vector was constructed which, in addition to $4 \mathrm{~kb}$ of 5 '-flanking DNA, also contained the initial $12.8 \mathrm{~kb}$ of DNA from the first intron of the ADA gene. This large fragment from the intron was inserted into the CAT vector, $3^{\prime}$ to the SV40 $\mathrm{T}$ antigen splicing and polyadenylation signals, in the same orientation to the promoter as in the parent ADA gene. In this manner, we essentially replaced the translated portion of the first exon of the ADA gene with sequences for coding, splicing, and polyadenylation of CAT mRNA. The structures of the transgenes, the largest plasmid construction, pADA CAT 4/12, and the segments of the human ADA gene that are contained in it are depicted in Figure 1. From pADA CAT 4/12, four DNA fragments were derived to be used as transgenes: three that divided the intron fragment into approximate thirds, and one that removed 594 bp of $5^{\prime}$-flanking DNA only.

\section{CAT enzyme expression in transgenic mice}

The specific activity of CAT enzyme in extracts of various tissues taken from independent lines of transgenic mice is indicated in Table 1. Inclusion of either 8.5 or $12.8 \mathrm{~kb}$ of the intron segment led to a pattern of dramatically increased CAT expression. Only very low levels of CAT enzyme could be detected in tissues of all transgenic mice made with DNA constructions that contained up to $3.7 \mathrm{~kb}$ of $5^{\prime}$-flanking DNA (ADA CAT $0.2,2.2$, and 3.7; the transgene ADA CAT 3.7 contained only $3.7 \mathrm{~kb}$ out of the $4 \mathrm{~kb}$ in the plasmid because of restriction endonuclease site considerations). The inclusion of up to $4.3 \mathrm{~kb}$ of the first intron combined with 3.7 $\mathrm{kb}$ of 5'-flanking DNA (ADA CAT 3.7/4.3) also gave low and apparently random CAT activities. In contrast, very high levels of CAT activity were detected consistently in all six independent lines of mice made transgenic with constructions that contained at least $8.5 \mathrm{~kb}$ of the first intron (ADA CAT 3.7/8.5, 3.4/12, and 4/12). Within each of these high-expressing mouse lines, the thymus exhibited CAT activity one to two orders of magnitude higher than the tissues of next highest activity. Among ADA CAT 4/12 and ADA CAT 3.4/12 mice, the tissues that were consistently second to thymus in CAT activity were the spleen, bone marrow, and stomach. Although five of five transgenic lines that contained 12.8 $\mathrm{kb}$ of intron DNA showed moderately high CAT activity in the stomach, the one transgenic line that contained only $8.5 \mathrm{~kb}$ of intron did not.

CAT expression in transgenic mouse lines that lacked the intronic sequences exhibited several noteworthy features. First, CAT activity generally was observed in the ovaries of transgenic mice that contained ADA CAT 0.2 . Some of these lines also expressed CAT in other apparently random tissues, in all cases at lower levels than each did in its ovary (Table 1). Second, two of three lines of transgenic mice that contained ADA CAT $2.2 \mathrm{ex}$ pressed CAT exclusively in the thymus. However, extrapolating from the specific activity of each enzyme in even the more active thymus, the mass quantity of CAT enzyme was $<0.01 \%$ that of ADA. By comparison with the ADA CAT 4/12 mice, the presence of sequences contained in the intron fragment increased thymic CAT activity by 10,000- to 2 million-fold. A third line of $\mathrm{ADA}$ CAT 2.2 failed to express CAT in its thymus but did so in the colon, brain, and bone marrow. Finally, it is interesting to note that the ovarian expression of CAT was eliminated in ADA CAT 2.2 transgenic mice; similarly, thymic CAT expression was not observed in ADA CAT 3.7, which itself exhibited no consistent pattern of expression. Thus, if cis-regulatory elements with thymic or any other tissue specificity are contained within $5^{\prime}$ flanking DNA of the human gene-in the absence of se- 


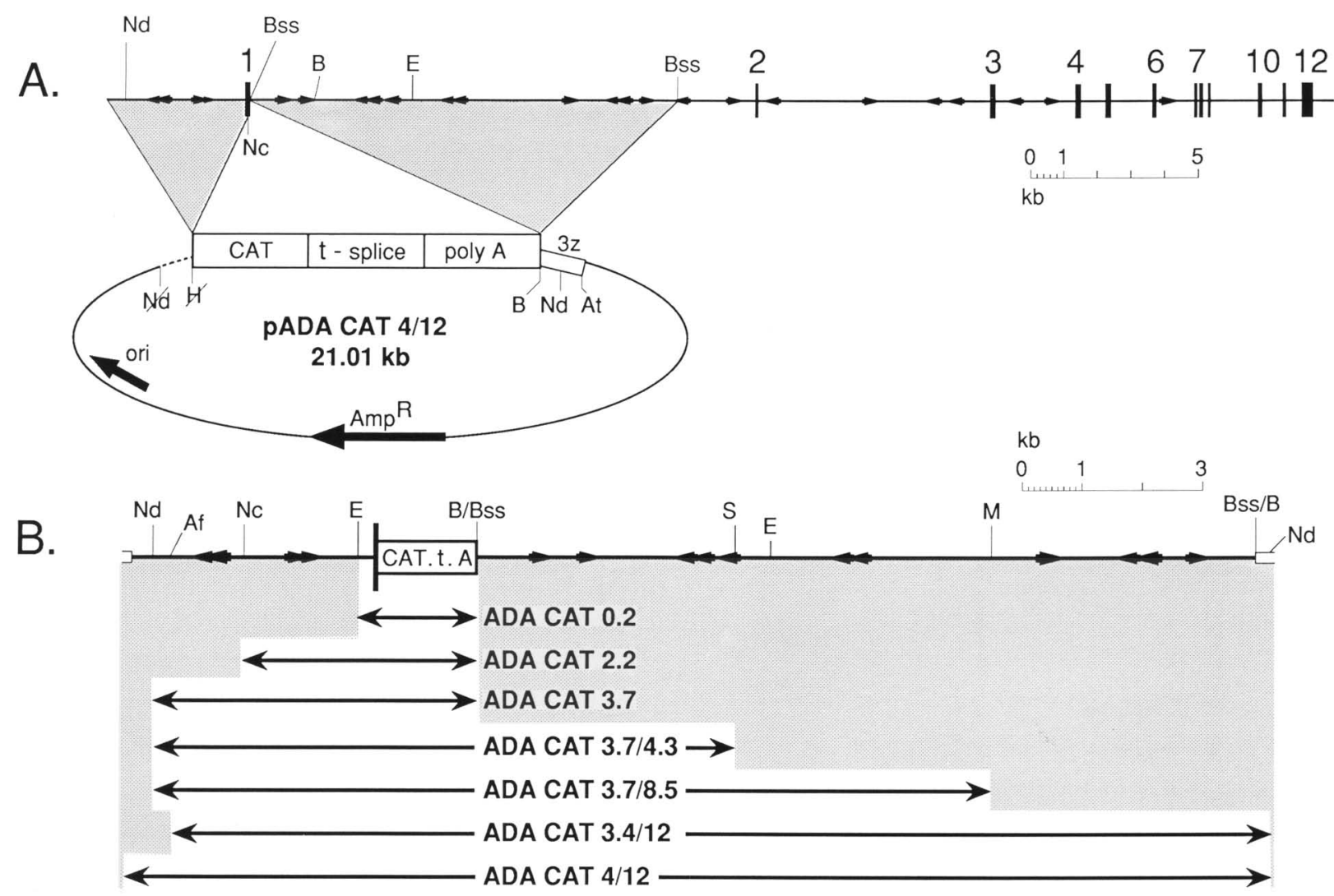

Figure 1. Reporter gene constructions. DNA fragments from the human ADA gene were inserted into the promoterless expression vector pSV0-CAT to create ADA CAT plasmids. The plasmids were digested with restriction enzymes to yield DNA fragments used to generate transgenic mice. $(A)$ Top line is a scale diagram of the human ADA gene and the segments from it used to generate the largest plasmid, pADA CAT 4/12. Vertical bars indicate exons; arrowheads indicate alu-type repetitive DNA sequences. In the construction of the plasmid, $5^{\prime}$-flanking DNA from the ADA gene replaced the sequences of pSVO-CAT between its NdeI and HindIII sites, and the large $B s s \mathrm{H} 2$ fragment from the first intron was inserted into the vector BamHI site. $(B)$ Transgene fragments derived from pADA CAT plasmids. The thick vertical bar indicates the $98 \mathrm{bp}$ of the ADA gene first exon up to the initiator codon that is linked to the CAT coding, splicing $(t)$, and polyadenylation $(\mathrm{A})$ sequences of pSVO-CAT. Restriction sites are indicated as referred to in materials and methods, and are not necessarily unique. (Af) AflII, (At) AatII, (B) BamHI, (Bss) BssHII, (E) EcoRI, (H) HindIII, (M) MluI, (Nc) NcoI, (Nd) Ndel, (S) SphI. All transgenes that contained intron DNA were derived from pADA CAT 4/12. Transgenes that contained only 5 -flanking DNA were derived from separate plasmids but are also illustrated.

quences contained in the first intron-such sequences would appear at their best to be weak and subject to the influence of the genomic integration site /for discussions of this type of effect, see Palmiter and Brinster 1986; Grosveld et al. 1987). In ongoing work, we are examining the effects of human ADA gene $5^{\prime}$-flanking DNA in transgenic mice in the context of the active intronic control sequences.

\section{Reporter versus endogenous gene expression}

To determine whether the CAT reporter gene functioned in a quantitatively similar manner to that of the endogenous mouse ADA gene in ADA CAT 4/12 transgenic mice, we determined the number of transgene copies in each line (Table 1) and the quantities of ADA and CAT mRNA in various tissues of control and transgenic mice by a quantitative solution-hybridization/ribonuclease A protection procedure (Fig. 2). Consistent with their relative expressions of CAT enzyme, lines c and d contained more copies of ADA CAT 4/12 transgenes than lines $\mathrm{a}$ and $\mathrm{b}$ did. CAT expression in most tissues of ADA CAT 3.4/12 and ADA CAT 3.7/8.5 mice was similar to that in ADA CAT 4/12 mice that contained similar transgene copy numbers. To observe the correlation of mRNA levels with enzyme activities, mRNA was measured in ADA CAT 4/12 lines b and $c$. In the ADA CAT 4/12 line b mouse, CAT mRNA was readily quantifiable in thymus, stomach, and spleen but below the detectable threshold in tongue, liver, and brain. In the line c mouse, CAT mRNA could be measured in all 10 tissues from which RNA was isolated. Data from these analyses are summarized in Table 2. The results indicate that both ADA and CAT mRNA levels generally paralleled the specific activities of their enzymes in each tissue extract, despite some variations among independent mice within some tissues (see, e.g., esophagus ADA mRNA levels in Table 2). The probe specific for CAT mRNA revealed the presence of a fulllength mRNA corresponding to the coding sequence of 
Table 1. CAT expression in tissues of mice made transgenic with a series of ADA CAT constructions

\begin{tabular}{|c|c|c|c|c|c|c|c|c|c|c|c|c|c|}
\hline \multirow[b]{2}{*}{ Gene construct I } & \multirow{2}{*}{ Line } & \multirow{2}{*}{$\begin{array}{l}\text { Copy } \\
\text { no. }\end{array}$} & \multicolumn{11}{|c|}{$\mathrm{CAT}$ activity (pmoles acetylated $/ \mathrm{hr} / 100 \mu \mathrm{g}$ protein) } \\
\hline & & & thymus & spleen & marrow & tongue & esophagus & stomach & duodenum & colon & liver & brain & ovary \\
\hline \multirow{4}{*}{ ADA CAT 0.2} & a & 100 & $0^{\mathrm{a}}$ & 0 & 0.1 & 0 & 0 & 0 & 0 & 0.8 & 0 & 0 & 28 \\
\hline & b & 150 & 0 & 0 & 0.6 & 0 & 2.4 & 0 & 0 & 0.2 & 0 & 0.3 & 27 \\
\hline & c & 50 & 0 & 0 & 1.3 & 0 & 0.7 & 0 & 0 & 0.1 & 0.1 & 17 & $160^{b}$ \\
\hline & $\mathrm{d}$ & 200 & 0 & 0 & 0 & 0 & 0 & 0 & 0 & 0 & 0 & 0 & 230 \\
\hline \multirow[t]{3}{*}{ ADA CAT 2.2} & a & 2 & 1 & 0 & 0 & 0 & 0 & 0 & 0 & 0 & 0 & 0 & 0 \\
\hline & b & 15 & 0 & 0 & 1 & 0 & 0 & 0 & 0 & 0.1 & 0 & 0.1 & 0 \\
\hline & $\mathrm{c}$ & 5 & 27 & 0 & 0 & 0 & 0 & 0 & 0 & 0 & 0 & 0 & 0 \\
\hline \multirow[t]{3}{*}{ ADA CAT 3.7} & a & 3 & 0 & 0 & 0 & 0 & 0 & 0 & 0 & 0 & 0 & 11 & 0 \\
\hline & $b$ & 3 & 0 & 0 & 0 & 0 & 0 & 0 & 0 & 0 & 0 & 0 & 0 \\
\hline & $\mathrm{c}$ & 7 & 0 & 0 & 0 & 0 & 0 & 0 & 0 & 0 & 0 & 0 & 0 \\
\hline \multirow[t]{3}{*}{ ADA CAT $3.7 / 4.3$} & a & 6 & 1.5 & 0.7 & 0 & 18 & 1.4 & 1 & 0.8 & 0.2 & 0 & 170 & $0.4^{\mathrm{c}}$ \\
\hline & $\mathrm{b}$ & 12 & 0 & 0 & 0 & 0 & 0 & 8.2 & 0 & 0 & 0 & 1 & 0 \\
\hline & $c^{d}$ & $\mathrm{ND}^{\mathrm{e}}$ & 0.1 & 0 & 0 & 0 & 0 & 0 & 3.4 & 0 & 0 & 1.5 & 0 \\
\hline ADA CAT $3.7 / 8.5$ & 5 a & 10 & 310,000 & 670 & 2,100 & 54 & 140 & 6 & 98 & 32 & 4.7 & 1.6 & 50 \\
\hline ADA CAT $3.4 / 12$ & $a^{d}$ & 8 & 160,000 & 500 & 770 & 200 & 250 & 1,400 & 380 & 380 & 7 & 170 & 200 \\
\hline \multirow[t]{4}{*}{ ADA CAT 4/12 } & $\mathrm{a}$ & 15 & 240,000 & 290 & 290 & 30 & 78 & 2,300 & 20 & 42 & 0.4 & 31 & $1^{\mathfrak{c}}$ \\
\hline & $\mathrm{b}$ & 10 & 220,000 & 660 & 1,100 & 100 & 330 & 3,700 & 30 & 150 & 1.3 & 540 & 92 \\
\hline & $\mathrm{c}$ & 100 & $2,000,000$ & 52,000 & 130,000 & 20,000 & 8,200 & 340,000 & 45,000 & 25,000 & 640 & 22,000 & $330^{c}$ \\
\hline & d & 60 & $1,800,000$ & 43,000 & 99,000 & 4,400 & 10,000 & 120,000 & 25,000 & 10,000 & 150 & 19,000 & $100^{c}$ \\
\hline
\end{tabular}

Extracts of individual tissues from individual mice were measured for their specific activity of CAT. Results of multiple independent transgenic lines are shown, along with the approximate number of transgene copies within each line. Except as noted, transgenic lines were established by breeding founder mice, using their $\mathrm{F}_{1}$ offspring for analyses.

a Less than detectable limit $(\sim 0.005)=0$. All activities detectable, but $<0.1$ were set $=0.1$.

b Nongonadal tissue expression pattern maintained in male sibling, but no activity was present in testes.

c Testes value.

d Founder mouse.

(ND) Not determined.

CAT and, in addition, a major and several minor aberrantly spliced forms of CAT mRNA in smaller bands than the CAT mRNA probe (Fig. 2). The production of these aberrant forms is unrelated to the presence of ADA gene sequences or to the transgenic mouse model, because similarly spliced CAT mRNAs occur in fibroblasts transfected with pRSV-CAT (B. Aronow, unpubl.; C. Gorman, pers. comm.|. The ratios of aberrant to fulllength CAT mRNAs varied somewhat according to tissue, for example, $1: 1$ in thymus and $3: 1$ in stomach (these respective ratios were similar in line $\mathrm{c}_{\text {; }}$ not shown). The smaller CAT mRNA species are probably unable to code for CAT enzyme because the CAT. coding sequence is truncated, but the sum of the species should represent a better approximation of the transcriptional activity of the transgene in each tissue. When mRNA levels (Table 2) are compared with CAT activities (Table 1), it appears that some of the differences in CAT mRNA levels in several tissues are less than would have been expected. For example, comparing stomach of line $c$ to line $b$, the ratio of mRNAs was $11: 1$, but the ratio of CAT enzyme activities was $90: 1$.

How closely do CAT mRNA levels correspond to the levels of mouse endogenous ADA mRNA in the various tissues? In thymus, the amount of CAT mRNA exceeded ADA mRNA by factors of 6 and 20 in lines $b$ and $\mathrm{c}$, respectively. Also in line $\mathrm{c}$ mouse bone marrow, CAT
mRNA exceeded endogenous ADA mRNA by nearly 14fold. However, even in line $\mathrm{c}$, the relative amount of CAT mRNA in the spleen was only slightly greater than the amount of ADA mRNA. In other tissues, CAT mRNA was present in much lower quantities than ADA mRNA. Taken as a whole, the results appear to indicate that the ADA CAT 4/12 construct contains critical regulatory elements capable of directing a level of CAT RNA that is comparable to ADA mRNA levels in the thymus and, possibly, bone marrow. However, on the basis of gene copy number, RNA levels generated by the transgene were not as high as those expressed by the endogenous gene in several tissues. This was the case in the spleen, stomach, and duodenum, and very much the case in the tongue and esophagus. Although we do not expect that CAT mRNAs and ADA mRNA would have identical tissue-specific stabilities, the results clearly suggest some strong differences between the expression patterns of the ADA CAT 4/12 transgene and the endogenous mouse ADA gene.

\section{Human versus mouse ADA expression}

To better understand some of the discrepancies between the patterns of CAT expression in the ADA CAT 4/12 mice and the endogenous mouse ADA gene, especially the lack of high-level expression in the upper gastroin- 


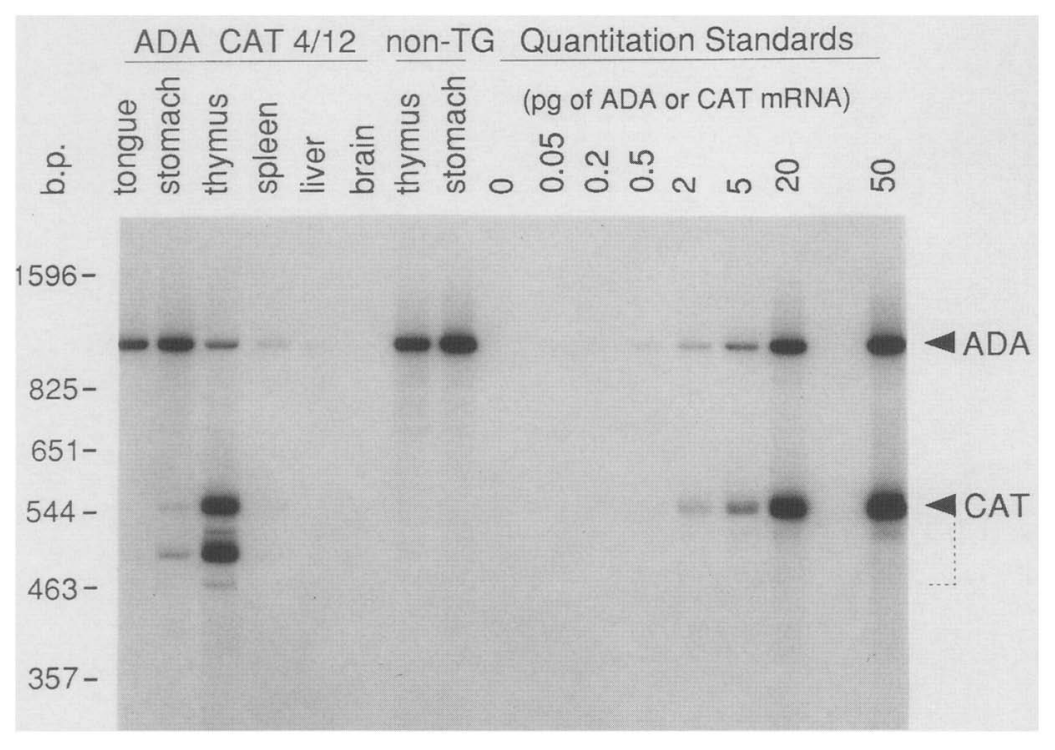

Figure 2. Quantitative determination of CAT and ADA mRNA. Radiolabeled RNAs anti-sense to the coding portions of ADA and CAT mRNAs were hybridized in solution to total RNA, digested with RNase A, and electrophoresed on nondenaturing $3.8 \%$ polyacrylamide gels. To quantify the RNAs, parallel hybridizations were performed also with spectrophotometrically determined quantities of sense-strand CAT and ADA RNAs prepared from transcription vectors. Each lane was loaded with the hybridizationprotection products of $20 \mu \mathrm{g}$ of total RNA, except for tongue, which was $0.6 \mu \mathrm{g}$. Full-length CAT mRNA protected a 550-bp fragment, and full-length ADA mRNA protected a 997-bp fragment. Smaller protected fragments represent aberrantly spliced CAT mRNAs. The autoradiograph shown was exposed for $12 \mathrm{hr}$ at $-70^{\circ} \mathrm{C}$ without an intensifying screen. testinal tract, we determined ADA activities in these tissues from humans. A moderate level of ADA activity has been reported in an unspecified portion of human duodenum (Van der Weyden and Kelley 1976). However, we observed ADA mRNA and enzyme to be almost entirely confined to the apical portions of duodenal villi in mice and humans (B. Aronow and D. Witte, in prep.). Enzyme in this location could be especially susceptible to necropsy-associated autolysis. Therefore, we obtained a variety of human surgical biopsy specimens, all of which were judged to be histologically normal, for assay of ADA. The results (Table 3 ) indicate a substantial divergence in the expression patterns of ADA in mice and men. Humans exhibit a low level of ADA activity in tongue and esophagus compared with mice. Like mice, however, humans do show evidence of elevated ADA activity in the stomach and duodenal mucosa. In spite of this, ADA CAT 4/12 transgenic mice consistently failed to express CAT in the duodenum much above the levels of the lower expressing tissues surveyed. However, a consistently elevated level of CAT expression was present in the stomach (Table 1).
Because ADA expression occurs at high levels in cortical thymocytes from a variety of mammals (Chechik et. al. 1981; 1983) and the levels of both CAT enzyme and mRNA were highest in thymus, we sought to determine where within the thymus ADA CAT 4/12 mice expressed the transgene by using in situ hybridization. Cryostat sections of thymus from an ADA CAT 4/12 line $c$ mouse and nontransgenic animals were incubated with radiolabeled RNA complementary to CAT mRNA. Using probe specific for CAT, a strong signal was obtained over dense clusters of cells within the thymic cortex (Fig. 3). Cells within the juxtamedullary cortex appeared to generate an especially intense signal, seen a bit more clearly in bright-field illumination. The transgenic thymic medulla exhibited substantially less signal, and thymus from a nontransgenic control animal exhibited no appreciable signal. We attempted also to determine the distribution of ADA mRNA in human and mouse thymus by in situ hybridization, but we were unable to obtain a convincing signal. Therefore, we used a chromogenic histochemical stain (Fig. 4) for the in situ detection of ADA enzyme activity (Spencer et al. 1968;

Table 2. mRNA quantitation in normal and transgenic mouse tissues.

\begin{tabular}{|c|c|c|c|c|c|c|c|c|c|c|c|}
\hline Mouse & $\mathrm{mRNA}^{\mathrm{a}}$ & Thymus & Spleen & Tongue & Esophagus & Stomach & Duodenum & Colon & Liver & Brain & Marrow \\
\hline \multirow{2}{*}{$\begin{array}{l}\text { ADA CAT } 4 / 12 \\
\text { (line b, } 10 \text { copies) }\end{array}$} & $\mathrm{ADA}$ & 2.5 & 0.65 & 160 & - & 8.5 & - & - & 0.1 & 0.05 & - \\
\hline & $\mathrm{CAT}^{\mathrm{b}}$ & 16 & 0.12 & $0^{\mathrm{c}}$ & - & 0.85 & - & - & 0 & 0 & - \\
\hline \multirow{2}{*}{$\begin{array}{l}\text { ADA CAT } 4 / 12 \\
\text { (line c, } 100 \text { copies) }\end{array}$} & $\mathrm{ADA}$ & 11 & 3.1 & 190 & 330 & 40 & 25 & 16 & 0.6 & 0.07 & 1.1 \\
\hline & $\mathrm{CAT}^{\mathrm{b}}$ & 230 & 4.4 & 0.8 & 0.6 & 9.6 & 0.9 & 0.4 & 0.04 & 0.1 & 15 \\
\hline Nontransgenic 1 & ADA & 7.8 & 0.3 & 150 & 60 & 9.6 & 32 & - & 0.15 & 0.1 & - \\
\hline Nontransgenic 2 & $\mathrm{ADA}$ & 9.0 & 0.2 & 250 & 200 & 7 & 60 & 2 & 0.08 & 0.1 & - \\
\hline
\end{tabular}

CAT and ADA mRNA contents in total RNAs from various tissues of transgenic and nontransgenic mice. RNAs from individual tissues from individual mice were subjected to the ribonuclease protection protocol described in Fig. 2 . Values were determined by scanning gels for surface radio emission (Betagen Corp.) and by densitometric scanning of autoradiographs exposed with or without intensification screens for varying lengths of time so as to optimize high-or low-level signals.

${ }^{\mathrm{a}} \mathrm{mRNA}=\mathrm{pg} / 10 \mu \mathrm{g}$ total RNA.

b Sum of full-length and aberrantly spliced forms of CAT mRNA.

c Below detectable limit, which was $\sim 0.02 \mathrm{pg} / 10 \mu \mathrm{g}$ total RNA. 

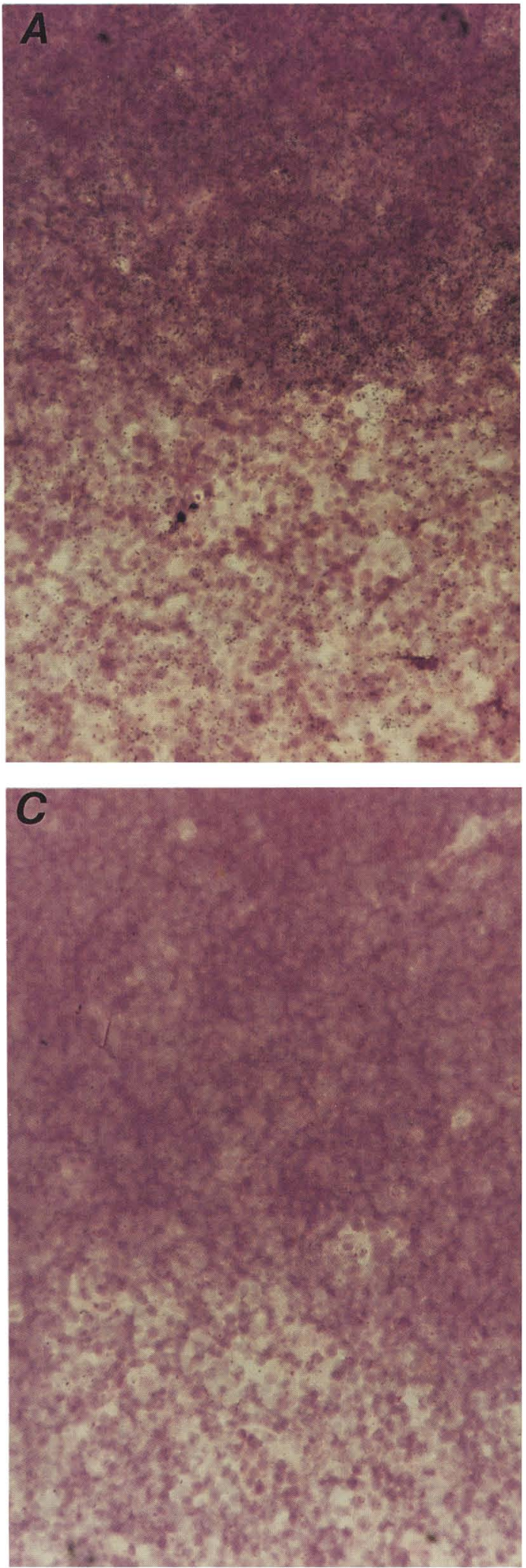
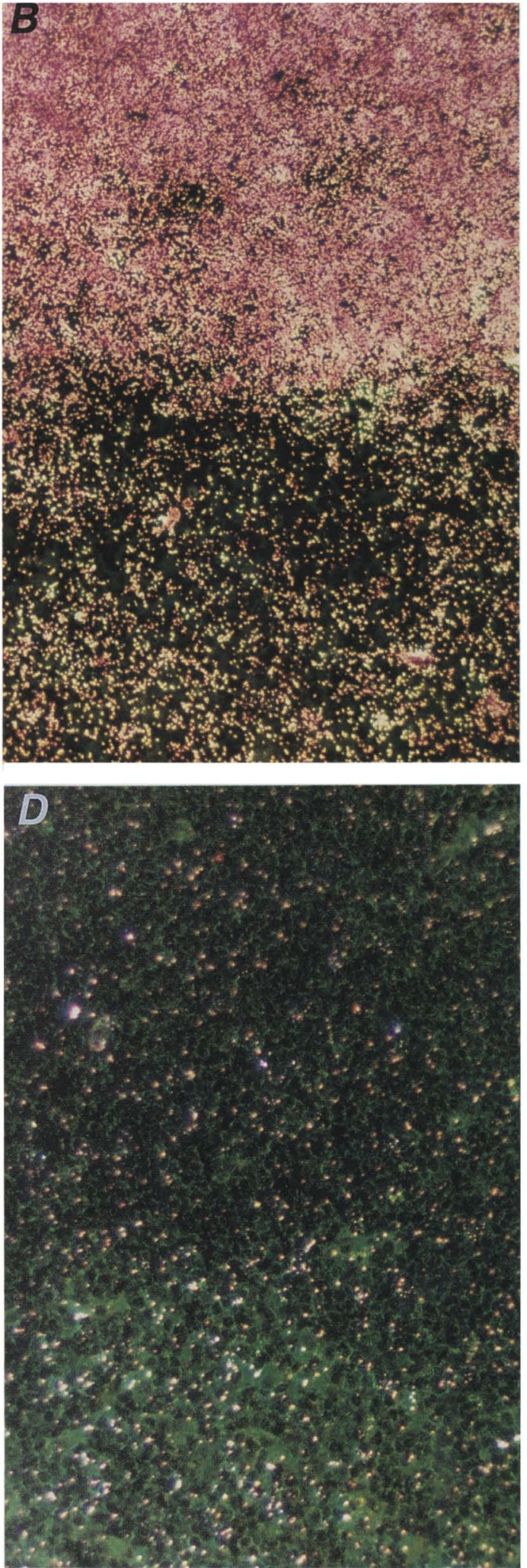

Figure 3. In situ hybridization of control and transgenic mouse thymus with $\alpha{ }^{-35}$ S labeled RNA complementary to CAT mRNA. $\mid A$ and $B)$ Thymus from a line c ADA CAT 4/12 mouse probed with anti-CAT RNA; $\mid C$ and $D \mid$ control mouse thymus probed with anti-CAT mRNA. ( $A$ and $C$ ) Bright-field illumination; $(B$ and $D)$ dark-field illumination. The upper half of each panel is cortical thymus, and the lower half is medullary thymus. Dense clusters of cells within the cortical zone are labeled intensely. Silver grains appear as black dots in bright-field, and purplish-white dots in dark-field illumination. These sections were exposed for $72 \mathrm{hr}$. Magnification, $770 \times$. 

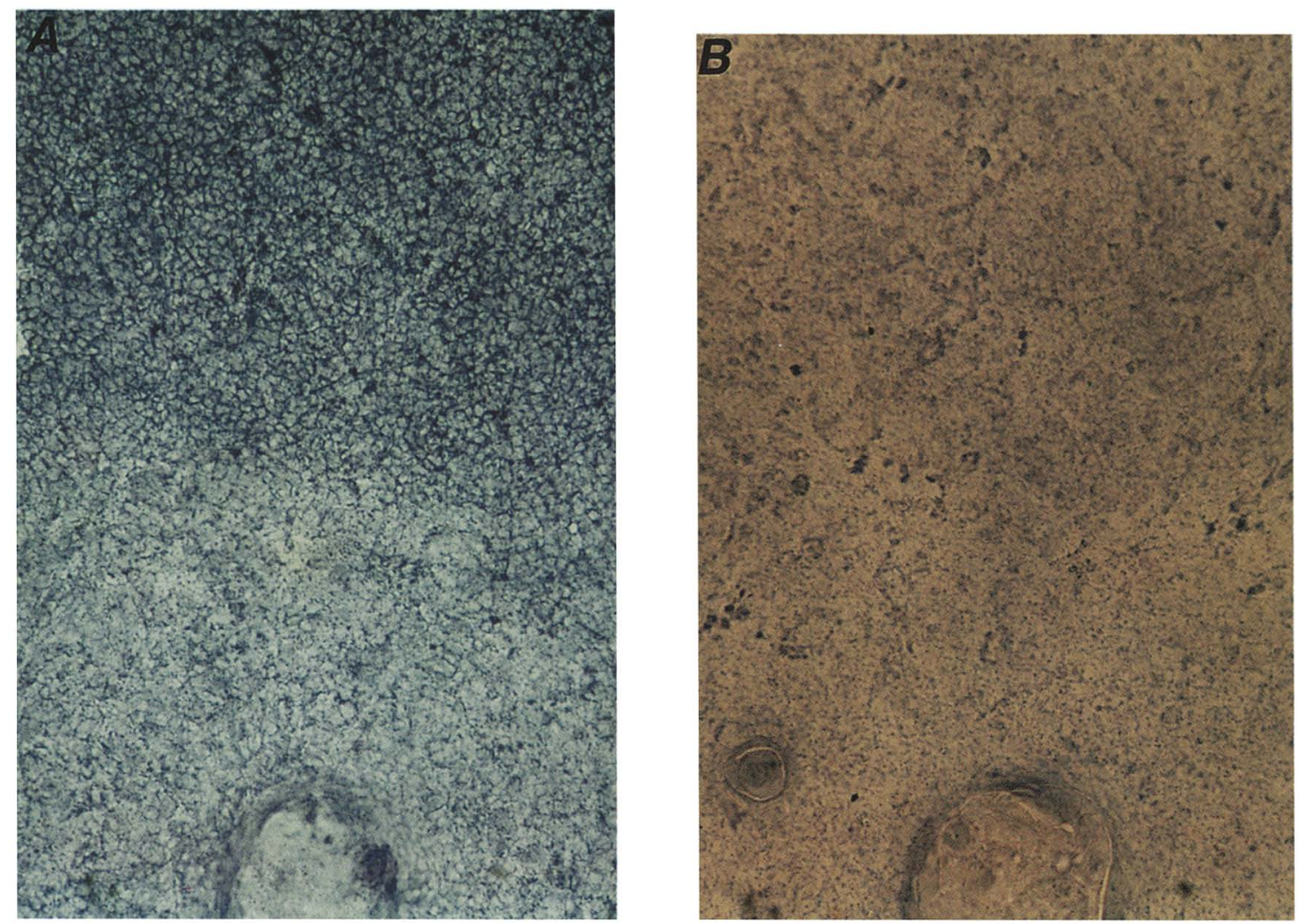

Figure 4. In situ histochemical stain for ADA enzyme activity in human thymus. Unfixed sections were made from the same thymus that was used for enzyme assays and DNase I-hypersensitivity studies. Sections were incubated with a chromogenic cocktail that detects ADA activity as a dense blue formazan precipitate. (A) Intense staining within the cortical regions (upper half); relatively less staining within the medullary regions (lower half). (B) Handled identically to $A$, except preincubated with deoxycoformycin, a potent and specific inhibitor of ADA activity, prior to the addition of the chromogenic cocktail. Hassall's bodies are evident in human, but not mouse, thymic medullae. Magnification, $770 \times$.

Knudsen et al. 1988). The results indicated that ADA activity was strongly detectable in the human thymic cortex (Fig. 4), with a less intense signal observed in the medullary region. A similar result was seen in mouse thymus (data not shown), and the appearance of the stain was completely blocked by deoxycoformycin, a potent inhibitor of ADA. Although we do not know the relationship of color intensity in situ to specific activity of ADA, the results do indicate a gradation of activity in cortical and medullary portions of the thymus. This distribution of ADA enzyme activity is essentially identical to that reported by Chechik et al. $(1981,1983)$, who used an immunohistological means of detecting ADA in a variety of mammals, including humans. Thus, the intrathymic distribution of ADA activity in human thymus is quite similar to the distribution of CAT mRNA in transgenic mouse thymus.

\section{DNase I hypersensitivity}

The pattern of CAT expression among the various transgenic lines suggested that essential regulatory elements of the human ADA gene lie in its first intron, 4.3-12.8 $\mathrm{kb}$ downstream of the first exon. To begin to identify the most critical sequences within this region and to assess whether characteristic chromatin structures occurred in human and various transgenic mouse tissues, we used DNase I hypersensitivity assays. To do this, nuclei from human thymus, several human cell lines, and a variety of tissues from ADA CAT 4/12 transgenic mice were analyzed. Sites within the first intron that were sensitive to DNase I digestion were mapped by indirect end labeling (Wu 1980). Autoradiograms of the indirectly end-labeled fragments that were generated by DNase I treatment of nuclei from the various tissues and cell lines are shown in Figure 5. A partial restriction map of the human ADA gene and the ADA CAT 4/12 transgene, and the locations from which probes were prepared, is shown in Figure 6 (top). Each probe coincided with the fragment ends generated by restriction endonuclease digestion of DNA purified from DNase I-treated nuclei. Within the nuclei that were studied, a total of six DNase I-hypersensitive sites were observed in the ADA intron, and each was mapped by molecular-weight determination of the DNase I liberated fragments. The individual sites discernible in each preparation of nuclei are indicated by Roman numerals adjacent to the autoradiograms in Figure 5, and the locations of these sites are summarized in Figure 6. Comparing the hypersensitive patterns generated from the different nuclei, there were 


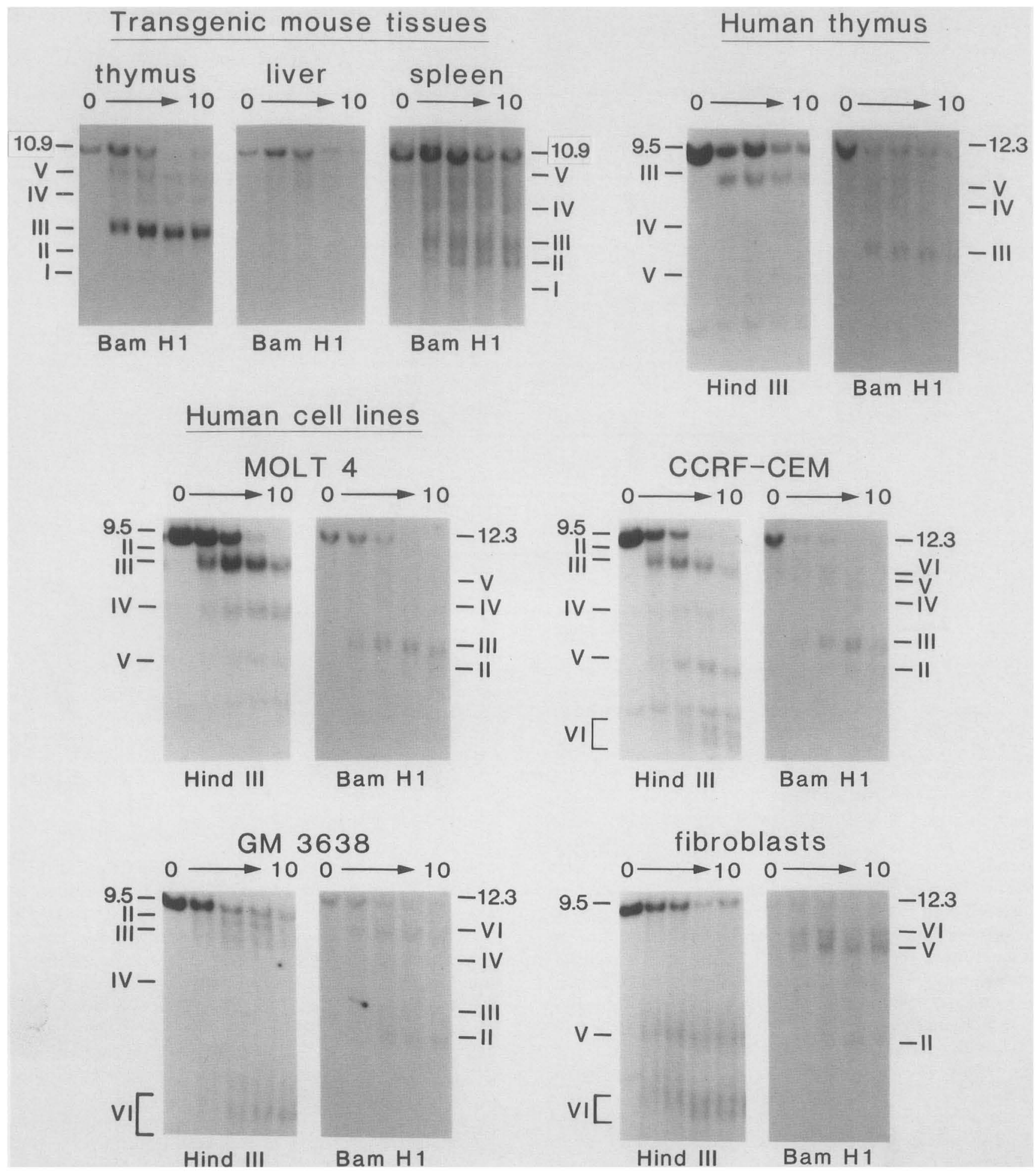

Figure 5. Tissue- and cell-type-specific hypersensitivity to DNase I in the human ADA gene first intron. Nuclei were isolated from tissues $(t o p)$ and cell lines (middle and lower) that differ in their expression of CAT and/or ADA. Nuclei were exposed to DNase I for $0,1,2.5,5$, and $10 \mathrm{~min}$ (indicated $0 \rightarrow 10$ for each group), DNA was purified, digested with BamHI or HindIII as indicated, electrophoresed through agarose gels, and transferred to Nytran filters. Filters from BamHI or HindIII digests were hybridized to the radiolabeled $5^{\prime}$ or $3^{\prime}$ probe, respectively (Fig. 6). The sizes of the restriction fragment parental bands in kilobases are indicated by arabic numerals in each autoradiogram. The fragments liberated by DNase I plus restriction enzyme are indicated by Roman numerals. The sizes of the various fragments were determined by comparison to known standards in each gel. In all BamHI digests, the fragments liberated by cleavage at hypersensitive sites I-VI are (at their midpoint of cleavage) $2.1,2.6,3.2,5.0,6.3$, and $7.1-7.8 \mathrm{~kb}$, respectively. In all $\mathrm{HindIII}$ digests, cleavage at hypersensitive sites I-VI gives fragments $9.4,8.9,8.3,6.5,5.2$, and 3.7-4.4 kb, respectively. Hypersensitivity analyses were performed on transgenic tissues from ADA CAT $4 / 12$ lines $\mathrm{c}$ and $\mathrm{d}$. 


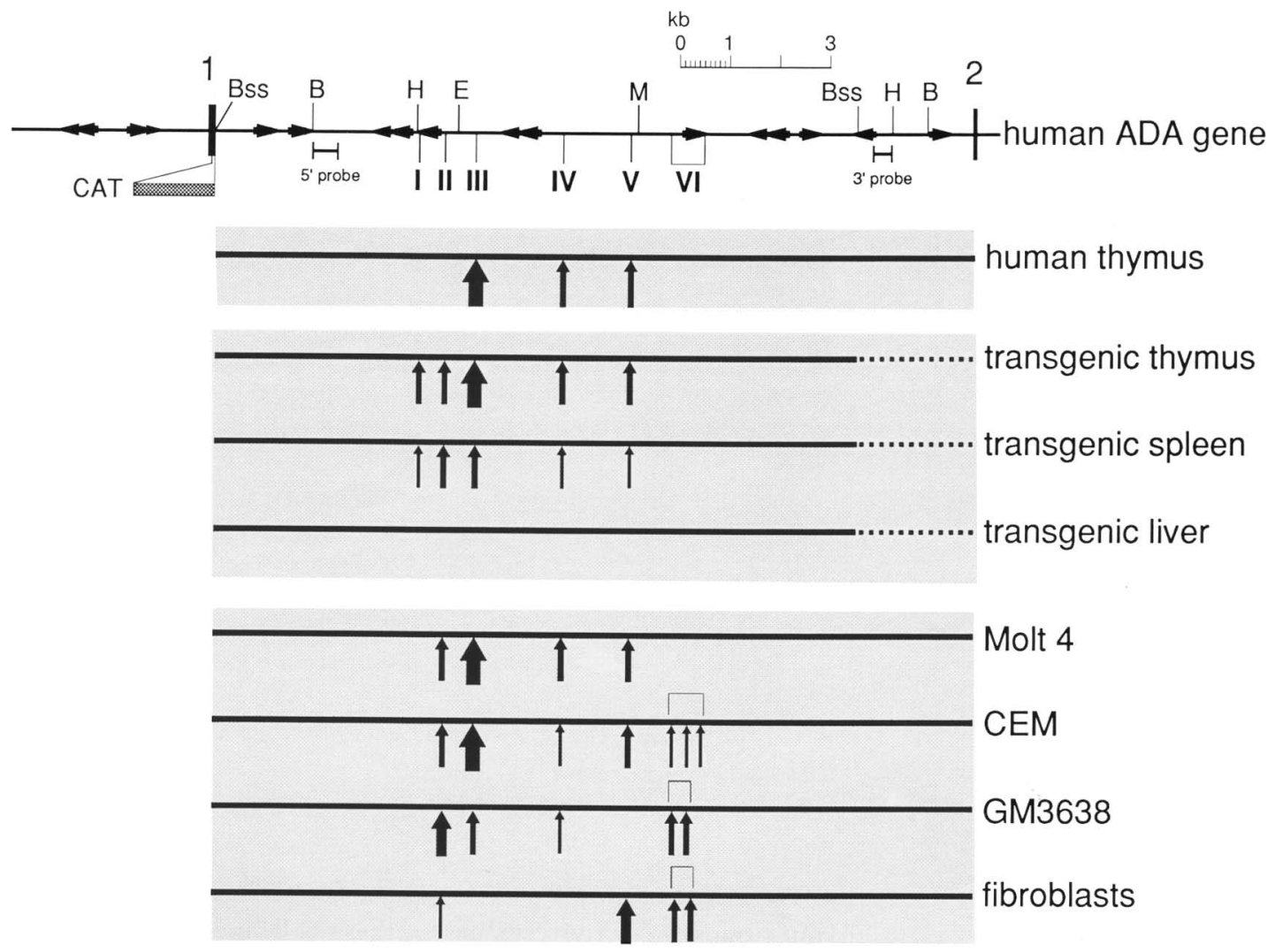

Figure 6. Summary of hypersensitive sites observed in the ADA gene first intron. (Top) Partial restriction map of the ADA gene. The ADA CAT 4/12 transgene has the same structure, except that it extends only to the 3' BssHII site and the first exon translated portion is replaced with CAT gene sequences. Hypersensitive sites I-VI, \{Fig. 5| are indicated as Roman numerals along the ADA gene map. Arrows under hypersensitive sites detected in each nuclear preparation indicate corresponding sites. The thickness of the arrow at each hypersensitive site approximates the relative intensities of the autoradiographic signals from each liberated fragment, as observed in Fig. 5. The position of the $3^{\prime}-$ BamHI site of the transgene is not shown, but this occurs at the $3^{\prime}$-BssHII site of the ADA gene first intron, as indicated in Fig. 1.

variations in both the particular hypersensitive sites that were detected and in the intensities of the liberated fragments. In Figure 6, the arrow thicknesses at each hypersensitive site are meant to approximate the relative intensities of the autoradiographic signals from each liberated fragment. Hypersensitive sites present in human thymus and cultured cell lines were confirmed independently by using the $5^{\prime}$ and $3^{\prime}$ probes (Fig. 6).

Human thymus and the human T-lymphoblastoid cell line Molt 4 exhibit high-level ADA gene expression (Tables 3 and 4, respectively). CEM cells, also human T-lymphoblasts, exhibit moderately high expression of the ADA gene (Table 4). Intense hypersensitivity at site
III was observed in DNase I-treated nuclei from all three sources. Two regions of less intense hypersensitivity also occurred in these digested samples at sites IV and V. Molt 4 and CEM cell nuclei also exhibited minor hypersensitivity at site II, and CEM additionally exhibited minor hypersensitivity at site VI. In contrast, the human B-lymphoblastoid cell line (GM3638) exhibited only minor hypersensitivity at site III, and the fibroblast cell line exhibited no hypersensitivity at that site whatsoever. Both the B-lymphoblastoid and fibroblast cell lines express ADA at low levels (Table 4), and we have previously shown this to be attributable, at least in part, to relatively low rates of ADA gene transcription (Lattier et

Table 3. Comparison of extracts from mouse and human tissues for their specific activities of ADA

\begin{tabular}{|c|c|c|c|c|c|c|c|c|c|c|c|}
\hline ADA activity ${ }^{a}$ & Thymus & Spleen & Marrow & Tongue & Esophagus & Stomach & Duodenum & Colon & Liver & Brain & Ovary \\
\hline Mouse, nontransgenic & 440 & 100 & 86 & 3500 & 3000 & 500 & 1000 & 56 & 11 & 2 & 28 \\
\hline Human & 790 & $130^{\mathrm{b}}$ & 5.3 & 19 & 10 & 200 & 570 & 25 & $8^{b}$ & $27^{b}$ & $-^{c}$ \\
\hline
\end{tabular}

Extracts represent those of individual mice or humans.

a $\mathrm{ADA}$ activity $=\mathrm{nmoles} / \mathrm{min} / \mathrm{mg}$ protein.

b From Van der Weyden and Kelley (1976).

c Not done. 
Table 4. ADA activities in extracts of human cell lines

\begin{tabular}{lc}
\hline Cell line & $\begin{array}{l}\text { ADA activity } \\
\text { (nmoles/min/mg protein) }\end{array}$ \\
\hline MOLT 4 & 1650 \\
CCRF-CEM & 270 \\
RAJI & 14 \\
GM3638 & 18 \\
GM4429B & 5 \\
\hline
\end{tabular}

al. 1989). Interestingly, the B cell line exhibited its most prominent hypersensitivity at site II, thus reversing the relative hypersensitivities of sites II and III that were observed in the thymus and the $\mathrm{T}$ cell lines. Similar to CEM cells, the B cell line exhibited minor hypersensitivity at site VI. Fibroblasts exhibited the most prominent hypersensitivity at site $\mathrm{V}$, somewhat less in the site VI region, and a minor signal from site II.

Transgenic mouse thymus and spleen exhibited hypersensitivity at virtually identical sites within the transgene, as occurred in the intact human ADA gene. As was the case in the human thymus, transgenic thymus exhibited very intense hypersensitivity at site III, with moderate hypersensitivity also occurring at sites IV and V. Transgenic spleen exhibited a similar pattern of hypersensitivity to that of thymus, except that site III was proportionately much less hypersensitive. Like Molt 4 cells, but unlike human thymus, transgenic thymus and spleen both exhibited moderate hypersensitivity at site II. Transgenic thymus and spleen were the only samples exhibiting hypersensitivity at site I. The ability to detect this site, however, may partly relate to the strong signal generated by large copy numbers of transgenes. An alternative explanation may be that hypersensitivity at this site results from a transgenic artifact, albeit a reproducible one, in both lines $\mathrm{c}$ and $\mathrm{d}$. In the HindIII-digested DNAs from all tissue sources, also we noted the presence of a hybridization signal in a band just larger than that generated by hypersensitivity at site VI. This band may represent an actual hypersensitive site, but several features suggest that this is not the case. The site was not detectable when probed from the 5 ' end (BamHI, Fig. 6), the intensity of the band generally was not increased by DNase I, and it was detectable also when the DNA was purified directly from cells rather than nuclei.

Transgenic liver, which expressed both CAT and ADA at very low levels, lacked any detectable regions of DNase I-hypersensitivity. Similarly, nuclei from kidney, which also expressed only low levels of CAT and ADA in all mouse lines, also failed to exhibit DNase I hypersensitive sites within the transgene intron /data not shown). As a further control, limited DNase I digestion of purified high-molecular-weight DNA isolated from CEM cells was performed also, and as expected, no DNase I hypersensitivity within the intron was found (data not shown).

DNA isolated from DNase I-treated thymic nuclei of ADA CAT 4/12 transgenic mice was also studied for the presence of hypersensitive sites outside of the regions indicated in Figure 6. Data from these experiments will be presented elsewhere in a study of the ADA gene promoter and 5'-flanking DNA. However, in general terms, there was much less hypersensitivity in any of the 5'flanking DNA, including sequences in the core promoter region, than was observed in Figure 5 (data not shown).

\section{Enhancer activity}

To begin to determine how sequences within the first intron activated high-level thymic expression in transgenic mice, we transfected a series of ADA CAT plasmid constructions (Fig. 7A) into several human lymphoid cell lines (Fig. 7B). The cell lines differ both in their endogenous expression of ADA and, as described above, in their pattern of DNase I hypersensitivity. DEAE-dextran-mediated transfection of pADA CAT 0.2 generated similar amounts of CAT activity in extracts of the three cell lines that were tested. The further addition of $3.8 \mathrm{~kb}$ of 5 '-flanking DNA to the construction, pADA CAT 4.0, inhibited CAT expression in all three cell lines. The inclusion of the entire $12.8-\mathrm{kb}$ intron fragment in pADA CAT 4/12 activated CAT expression. Comparing the three cell lines, CAT activity was very high in Molt 4 cells and progressively less in CEM and RAJI cell lines. This gradation is similar to that observed for the expression of the ADA gene in these cell lines (for ADA activity values in these cell lines, see Table 4). As stated above, the variations in ADA expression among these cell lines correlate well with their relative transcription rates of the gene (Lattier et al. 1989). When placed within the plasmid in an inverted orientation, pADA CAT 4/12inv, the intronic fragment, also activated CAT expression. A construction encompassing hypersensitive sites I and II (pADA CAT 4/5) showed very little, if any, activation of CAT expression in any of the cell lines. In Molt 4 cells, a construction encompassing hypersensitive sites II and III (pADA CAT 4/il.3) was expressed at a level similar to that of pADA CAT 4/12. Interestingly, in CEM and RAJI cell lines, this plasmid was not expressed nearly as well as pADA CAT 4/12 was. In CEM cells, pADA CAT $4 / \mathrm{il} .3$ was expressed at $10 \%$ of the level of pADA CAT $4 / 12$, and this was a significant increase over the level of CAT expressed by pADA CAT 4.0. In RAJI cells, pADA CAT $4 / 11.3$ was expressed at $10 \%$ of the level of pADA CAT $4 / 12$. However, this activity did not represent a significant increase over the level of CAT expressed by pADA CAT 4.0. Thus, sequences encompassing hypersensitive sites II and III contained a majority of the enhancer activity shown by the 12.8 - $\mathrm{kb}$ intron fragment in Molt 4 cells. In contrast, these sequences did not activate CAT expression in CEM and RAJI cells nearly to the extent as those of the 12.8 - $\mathrm{kb}$ intron fragment.

Another interesting difference among the cell lines occurred with pADA CAT $0.2 / 12$, a construction that contained the $12.8 \mathrm{~kb}$ intronic fragment, but the short promoter only. Molt 4 cells transfected with pADA CAT $0.2 / 12$ expressed a very high level of CAT activity that was 62 -fold higher than PADA CAT 0.2 and almost two- 


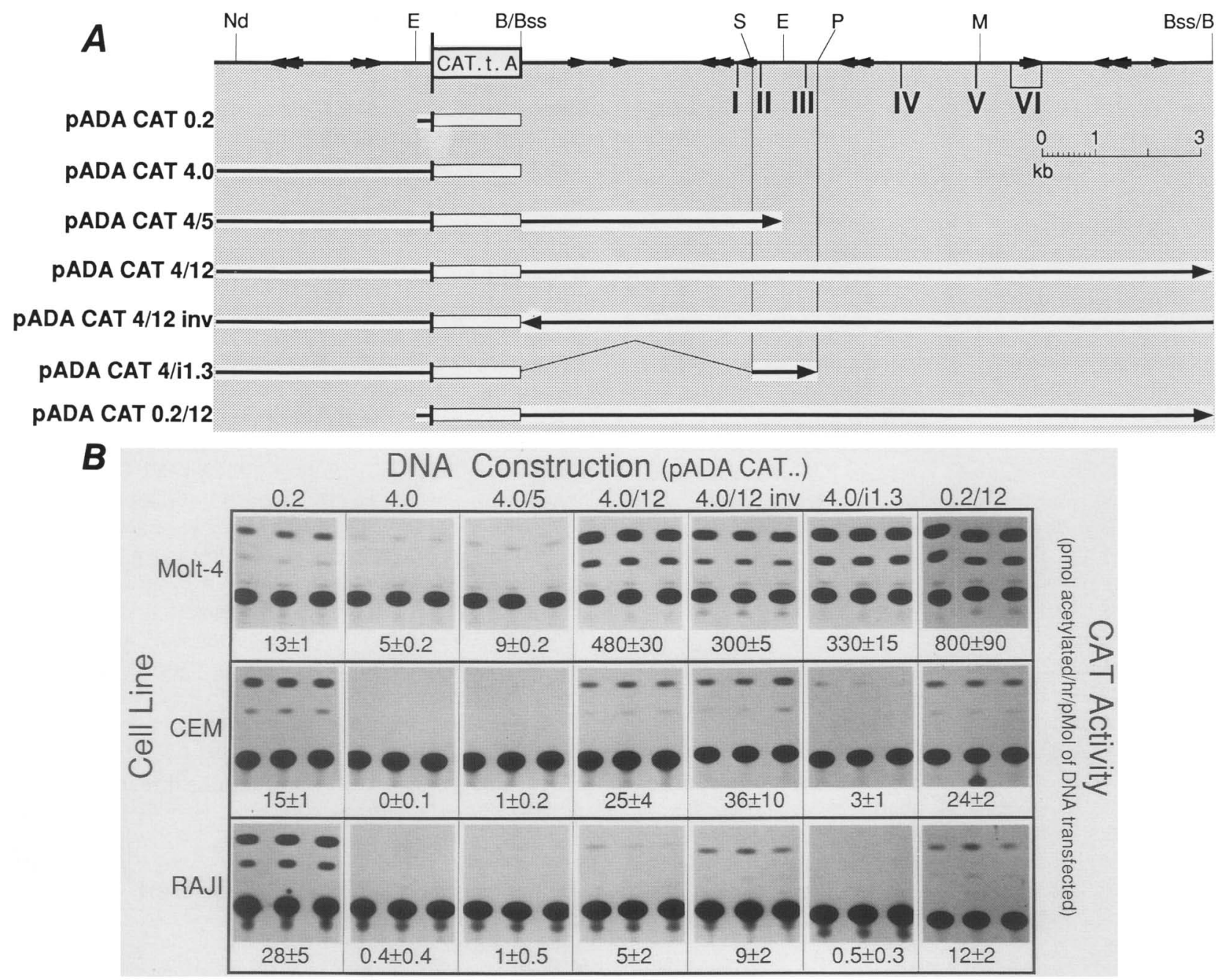

Figure 7. Transfection-transient expression analysis of pADA CAT DNA constructions. A series of DNA constructions containing various $5^{\prime}$ and first intron segments of the human ADA gene were transfected into three human lymphoblastoid cell lines differing in their endogenous expression of ADA. $(A)$ Plasmid constructions used to transfect human lymphoblastoid cell lines. CAT sequences, ADA gene segments contained within the plasmids, and their relation to the DNase I-hypersensitive sites. Direction of arrows in each construction refers to the orientation of the corresponding segment within the plasmid. Vector sequences are not shown. Symbols and abbreviations are as in Fig. 1. (P) PfIMI. $(B)$ CAT activities in extracts from lymphoblastoid cells transfected with the ADA CAT constructions. Each CAT reaction represents the assay of an independently performed DEAE-dextran-mediated transfection, with 15 $\mu \mathrm{g}$ of the indicated supercoiled plasmid. Acetylated products (upper two spots in each panel) were cut from thin-layer chromatograms and quantitated by scintillation spectrometry. Control experiments indicated that CAT activities in these transfections were linear with respect to the amount of DNA transfected, up to $15 \mu \mathrm{g}$ of DNA. Therefore, CAT activities were normalized for picomoles of DNA transfected, which differed by a factor of up to 4.43 among the various DNA constructions. CAT values are listed \pm SD. ADA activities in these cell lines are listed in Table 4.

fold higher than pADA CAT 4/12. Within Molt 4 cells, then, the enhancer element|s) of the intron appear to interact with the core promoter sequences to produce the majority of their effects. The results observed for CEM and RAJI cells are not interpreted easily. In both cell types, expression of pADA CAT $0.2 / 12$ was similar to that of pADA CAT 0.2 . Thus, the intronic enhancer(s) recognized in these cells had no effect on the core promoter sequences, and their effects are only noticeable relative to the constructs that also contained $4 \mathrm{~kb}$ of $5^{\prime}$ flanking DNA. The results suggest that in contrast to the situation in Molt 4 cells, the intronic enhancer(s) ac- tive in CEM and RAII cells appear to act principally by overcoming the effects of the 5 '-flanking inhibitory sequences. A mechanism for such an interaction remains to be determined.

\section{Discussion}

To study regulatory mechanisms employed by the human ADA gene, we examined the pattern of expression of chimeric reporter genes when introduced into mouse genomes. DNA from the 5 -flanking region of the ADA gene was most noteworthy for its inability to pro- 
mote a significant level of reporter gene expression. However, a powerful influence was exerted by a large DNA fragment from the first intron of the human gene. The intron fragment activated the expression of the CAT reporter gene linked to human ADA gene promoter sequences to generate extraordinarily high levels of CAT enzyme in the thymus, moderately high levels in the spleen, bone marrow, and stomach, and low levels throughout most other tissues of the resulting transgenic mice. In the thymus, where ADA mRNA comprises only $0.00008 \%$ of total RNA, CAT mRNA levels generated in ADA CAT 4/12 mice exceeded endogenous levels of ADA mRNA by factors that were similar, though not identical, to the numbers of transgene copies that were present. This similarity was generally not the case in the other tissues. However, based on the CAT mRNA levels and the specific activities of CAT enzyme in the various tissues, some degree of transgene copy proportional expression may also be estimated to have occurred in the other tissues. The failure to observe CAT expression at the level of the endogenous ADA gene in many of the mouse tissues could be due to (1) the absence of specific regulatory elements from the constructs, (2) the inability of the regulatory elements that are present to act within the context of the construct, or (3) cross-species differences in cis- and trans-regulatory mechanisms. Because we had not been aware of differences between patterns of ADA expression in mouse and human tissues, we were surprised to see that some of the highest expressing tissues of mouse, namely tongue and esophagus, were among the lowest expressers of ADA in man. We do not know why mice express high levels of ADA in tongue and esophagus. The goal may well be the expression of purine catabolic functions in digestive mucosa, such as occurs in the stomach and duodenum of both humans and mice. In this context, it is noteworthy that high levels of triglyceride lipase have been reported in the tongue of mice and rats (DeNigris et al. 1988). The level of lipase in mouse tongue was nearly 400 -fold higher than was observed in human tongue. Interestingly, human stomach did express significant levels of the enzyme.

When genes from one species are introduced into the genome of another, questions arise as to the ability of host trans-acting factors to recognize the incoming regulatory elements, especially when the expression patterns differ markedly between species (for a discussion of this effect, see Gordon et al. 1987). In the case of ADA CAT $4 / 12$ mice, the overall pattern of CAT expression was quite similar to that exhibited by $\mathrm{ADA}$ enzyme in humans but contrasted substantially with ADA expression in the mouse. In several genes, the pattern of expression of the transgene has been found to most closely resemble that of the introduced gene rather than that of the endogenous gene, for example, Thy-1, (Gordon et al. 1987); $\alpha_{1}$-antitrypsin (Kelsey et al. 1987). This phenomenon is most likely the result of the tissue-specific conservation of trans-acting factors across species, with a gene-specific divergence of cis-regulatory control elements. Therefore, it is not surprising that the ADA CAT transgenes derived from the human ADA gene lack the extremely high level of ADA expression that we have observed in the mouse upper gastrointestinal tract.

Have we incorporated all of the regulatory elements essential for the human pattern of ADA gene expression? We doubt that this is the case. CAT expression, both at the protein and RNA level, was elevated somewhat in several tissues such as stomach and spleen but, nevertheless, not as high as we might expect, on the basis of a comparison of enzyme activities in mice and humans and the RNA levels observed in the transgenic mice. The situation is even more clear in duodenum, a tissue of high-level expression in mice and humans but where CAT expression was relatively low. Thus, it is possible that additional regulatory domains will be found in or near the human ADA gene. However, for the reasons outlined above, we cannot be sure of this point. We are also uncertain as to the appropriateness of the relatively high-level expression of CAT that occurred in the transgenic mouse bone marrow. Enzyme assays of extracts from several human bone marrow aspirates suggest that much lower levels of ADA occur in human marrow than in mouse marrow. In further studies of this question, we have used fluorescence-activated cell sorting to determine the cell types within the transgenic marrow and thymus that exhibit high-level CAT expression (B. Aronow, C. Guidos, and I. Weissman, in prep.).

The largest transgene constructions directed a level of expression within the thymus that was consistent with the presence of critical thymic regulatory sequences. As judged by in situ hybridization, CAT mRNA in the thymus was skewed strongly to cortical thymocytes, a mixed population of cells undergoing a series of differentiation events associated with the development of an immune repertoire (Adkins et al. 1987). Because cell death is an important component of intrathymic selection and maturation (Mcphee et al. 1979), it is logical to consider a role for ADA in thymic purine homeostasis. The hypothesis would be that ADA is expressed in thymocytes at high levels to catabolize adenosine and deoxyadenosine liberated by the hydrolysis of nucleic acids that must accompany programmed thymocyte cell death. These compounds accumulate in children with ADA deficiency, especially in the relatively protected intrathymic environment, and are toxic to thymocytes, most likely by more than a single mechanism (for review, see Carrera and Carson 1987).

What sequences were critical for the high level of thymic CAT expression by ADA CAT 4/12 transgenic mice? As presented in Results, deletion analysis of the ADA CAT 4/12 transgene indicated that critical sequences were contained within the intron, $4.3-8.5 \mathrm{~kb}$ downstream of the first exon. Because Grosveld et al. (1987) and Ryan et al. (1989) have shown that the incorporation of super-hypersensitive domains flanking the human $\beta$-globin locus confers high level expression of $\beta$-globin miniloci, we sought to determine whether DNase I-hypersensitive sites were present within the intron. The formation of DNase I-hypersensitive sites has been associated with a variety of functional sequences 
such as those in promoters, enhancers, silencers, origins of replication, and others (for reviews, see Elgin 1988; Gross and Garrard 1988). In a number of advanced analyses, the appearance of hypersensitive sites has been associated with binding by sequence-specific proteins (Wu 1980, 1984), notably trans-acting factors responsible for transcriptional regulation. In the present study we observed multiple DNase I-hypersensitive sites in an extended region of the intron $4-10 \mathrm{~kb}$ downstream of the $\mathrm{ADA}$ gene first exon. The locations of the hypersensitive sites were highly conserved in comparing human thymus, transgenic thymus, and the MOLT 4 T-lymphoid cell line-all high-level expressers of ADA. The array of hypersensitive sites differed only slightly in CEM T cells, despite their considerably lower expression of $\mathrm{ADA}$. The array was varied more dramatically in GM3638 B cells and was drastically different in GM4429B fibroblasts. Both of these cell lines exhibit much lower levels of ADA gene expression and ADA gene transcription than either of the $T$ cell lines (Lattier et al. 1989). Hypersensitivity was undetectable in the transgenic liver, one of the lowest expressers of ADA and CAT in mice.

To begin to study the functions of sequences within the human ADA gene first intron, we transfected ADA CAT constructions into human lymphoid cell lines that exhibit high-, medium-, and low-level expression of the ADA gene. CAT expression from the ADA CAT 4/12 plasmid paralleled the relative expression of ADA in the three cell lines. Furthermore, as described in Results, comparison of the various constructs suggested that at least two mechanistically different kinds of enhancer activities were determined by sequences within the intron. In Molt 4 cells, intronic enhancer sequences were capable of strongly activating the function of the $0.2-\mathrm{kb}$ core promoter sequences. This did not appear to be the case in CEM and RAJI cell lines. Instead, the activating effects of the 12.8-kb intron fragment were apparent only when compared with the inhibited expression of the $4.0-\mathrm{kb}$ promoter. The intron did not have a discernible effect on the $0.2-\mathrm{kb}$ promoter. Additionally, the effects of the 12.8-kb intron fragment in CEM and RAJI cells were only to the extent of overcoming inhibitory effects of the $4.0-\mathrm{kb}$ promoter. Another difference was that in Molt 4 cells, most, though possibly not all, of the enhancer activity of the intron could be localized to sequences encompassing hypersensitive sites II and III. In contrast, CAT expression by the ADA CAT 4/i1.3 plasmid in CEM and RAJI cells was not very different from that of ADA CAT 4.0. One possibility to account for this is that sequences other than those of hypersensitive sites II and III are required for the intron to act as an enhancer in CEM and RAJI cells. Another possibility is that the il .3 fragment does, in fact, contain enhancer sequences for these cells, but the ability of the sequences to act on the $4.0-\mathrm{kb}$ promoter is somehow limited within the construct. The differences between Molt 4 and CEM cells are especially intriguing in light of their very similar patterns of DNase I hypersensitivity that differed only in region VI. As a whole, the results appear to suggest that virtually identical chromatin hypersensitivity structures may differ dramatically in their effects on gene expression. One hypothesis to explain this phenomenon is that one set of trans-acting factors are essential for the determination of chromatin structure, and additional others may be essential for mediating functional effects upon gene expression.

Although many genes of higher organisms contain large introns, it is still not clear that introns are a general site for the placement of critical cis-regulatory sequences. Enhancer and modulatory elements have been located within the introns of a growing list of genes, including those coding for mouse immunoglobulin chains (Banerii et al. 1983; Gillies et al. 1983), the Drosophila yellow locus (Geyer and Corces 1987), a number of collagen genes (see Bornstein et al. 1988), of chicken $\delta 1$ crystallin (Hayashi et al. 1987), and the mouse and human 4F2HC genes (Karpinski et al. 1989). Other types of cis-acting DNA sequences may also operate within introns. Brinster et al. (1988) suggested recently that introns contain cis-regulatory elements of an unknown nature, predicting the presence of something other than tissue-specific enhancer elements.

Severe combined immunodeficiency due to ADA deficiency has been cited frequently as a candidate for gene replacement therapy (Anderson 1984). Individuals with mutations that lead to ADA activity as low as $8 \%$ of normal levels exhibit apparently normal immune function (Hirschhorn and Ellenbogen 1986). Thus, even a low level of ADA expression among hematopoietic cell types by a replacement gene transferred into stem cells might correct the pathobiochemical basis of the disease. This might be especially true if expression were obtained in hematopoietic stem cells undergoing developmental differentiation within the thymus, producing functional $T$ lymphocytes. However, efforts have been impeded to this point partly because minigenes transferred into hematopoietic stem cells are expressed very poorly in differentiated cells (Dzierzak et al. 1988). One explanation for this failure is that gene constructions thus far have lacked critical regulatory sequences that allow for appropriately high-level expression (Grosveld et al. 1987). Evidence presented in this paper suggests that such sequences exist for the human ADA gene and that their function can be reconstituted in test constructions. It should now be possible to obtain the synthesis of ADA, and other polypeptides in developing thymocytes.

\section{Materials and methods}

Human tissues and cells lines

Thymus was taken from an individual child; tongue, esophagus, and bone marrow from individual adults; and mucosal biopsies of duodenum, stomach, and ileum from pooled specimens. All were obtained at surgery with consent and institutional approval, and were snap-frozen. The human bone marrow sample was the buffy coat from the first several milliliters of a bone marrow aspiration and contained relatively few erythrocytes. All tissues were examined microscopically and judged to be histologically normal. GM2219C (Molt 4) and 
GM3671C (CCRF-CEM, referred to throughout as CEM) are T-lymphoblastoid cell lines derived from human acute lymphoblastic leukemias. GM4671 (RAII) is a human B-lymphoid cell line derived from a human Burkitt lymphoma, GM3638A is a human B-lymphoblastoid cell line derived from a human acute leukemia, and GM4429B is an SV40-transformed human skin fibroblast cell line. All were obtained from the Human Genetic Mutant Cell Repository, Camden, New Jersey. Leukemic lymphoblasts were maintained in suspension culture at $37^{\circ} \mathrm{C}, 5 \%$ $\mathrm{CO}_{2}$ in RPMI-1640 (Flow Laboratories) without antibiotics, supplemented with $10 \%$ fetal bovine serum (Hyclone) and 2 mM L-glutamine. Fibroblasts were grown to confluence in $\alpha$ modified minimal essential medium (Flow Laboratories) with $10 \%$ fetal bovine serum (Hyclone).

\section{Reporter gene constructions}

DNA fragments of the human ADA gene were from the $\lambda$ clone ADA 194 (Wiginton et al. 1986) in EMBL 3 and were inserted into pSV0-CAT (Gorman et al. 1982) to create ADA CAT constructions. pSVO-CAT contains CAT coding, and SV40 t-antigen intron and polyadenylation sequences.

pADA CAT 0.2 A 232-bp EcoRI-Ncol fragment that contains the core promoter elements of the human ADA gene was inserted via blunt ligation into the HindIII site of pSVO-CAT.

pADA CAT 2.2 A 2.2-kb NcoI fragment overlapping with the above, but containing DNA that extends further $5^{\prime}$, was inserted by blunt ligation into the HindIII site of pSVO-CAT.

pADA CAT 4.0 The 5'-flanking region of pADA CAT 2.2 was extended by the insertion of the $3.2-\mathrm{kb}$ SalI-SacI fragment of $\lambda$ ADA 194 into NdeI-SacI cut pADA CAT 2.2, Sall and NdeI sites having first been repaired with Klenow polymerase.

pADA CAT 4/12 A 12.8-kb BssHII fragment, beginning 5 bases following the splice signal of the ADA gene first exon, was excised from BamHI-methylated $\lambda$ ADA 194, repaired, ligated to $B a m H I$ linkers, cut with $B a m H I$, and ligated into the BamHI site of a derivative of pADA CAT 4.0 that contained a unique $N d e$ I site, $3^{\prime}$ of the intron insertion. The derivative replaced the short BamHI-XmnI fragment of pADA CAT 4.0 with the homologous segment from pGEM3Z (Promega, Madison, Wisconsin). The 12.8-kb BamHI-linked intron fragment was incorporated in both orientations, giving pADA CAT 4/12 and pADA CAT 4/12inv.

pADA CAT 4/5 A 4.894-kb BssH2-EcoRI fragment from BamHI methylated $\lambda$ ADA 194, representing the first portion of the ADA gene intron, was repaired with Klenow polymerase, ligated to BamHI linkers, and then ligated into BamHI-cut pADA CAT 4.0 .

pADA CAT 4/i1.3 A 3.533-kb PflM I fragment, encompassing HS sites I-III, was repaired with T4 polymerase and blunt ligated into the SmaI site of pGEM3Z. From this, a BamHI-AatII fragment that included the PfIMI fragment was inserted into similarly cut pADA CAT 4.0 to give pADA CAT 4/i3.5. pADA CAT $4 / 11.3$ was derived from this plasmid by deletion of the 2.2-kb BamHI-SphI fragment, T4 polymerase repair, and selfligation.

pADA CAT 0.2/12 The BamHI linkered 12.8-kb BssH2 fragment was inserted into BamHI-cut pADA CAT 0.2.

\section{Fragments for transgenes}

ADA CAT DNA fragments for microinjection were prepared by digestion with $N d e I$ and BamHI (pADA CAT 0.2, pADA CAT 2.2, pADA CAT 4.0), or digestion with NdeI alone (pADA CAT 4/12). The NdeI sites of pADA CAT 0.2 and pADA CAT 2.2 are contained in the parent vector, adding 56 bp to the $5^{\prime}$ ADA sequence. Fortuitously, the 5' NdeI site of pADA CAT 4.0 and pADA CAT $4 / 12$ is within the $5^{\prime}$ ADA sequence, 3675 bp upstream of the initiator codon of the ADA gene exon 1 . The largest transgene, ADA CAT 4/12, was obtained following digestion with NdeI. Southern blot analysis of the four independent mouse lines established from this transgene demonstrated, however, that all $4 \mathrm{~kb}$ of 5 -flanking DNA and bacterial vector sequences were present in apparently all copies of the transgene. To rule out the role of the additional $5^{\prime}$-flanking DNA and to eliminate any effects of the bacterial sequences, another transgene, ADA CAT 3.4/12 was prepared by digestion (to completion) with AflII $(-3435)$ and AatII. Two additional transgenes were prepared from pADA CAT 4/12. ADA CAT 3.7/4.3 was obtained by digestion with NdeI and SphI, and ADA CAT $3.7 / 8.5$, by digestion with NdeI and MluI. Southern analyses confirmed that the resulting transgenic lines contained concatamers of the isolated fragments only. DNA fragments were isolated from agarose gels and prepared for microinjection using $\mathrm{CsCl}$, as described by Hogan et al. (1986).

\section{Transgenic mice}

Fertilized eggs of $(\mathrm{C} 3 \mathrm{H} \times \mathrm{C} 57 \mathrm{BL} / 6) \mathrm{F}_{1}$ hybrid parents were isolated, injected with DNAs, and implanted as described (Hogan et al. 1986). Transgenic pups were identified and bred to other $\mathrm{C} 3 \mathrm{H} \times \mathrm{C} 57 \mathrm{BL} / 6$ mice to obtain nonmosaic pups, all of which were analyzed between 4 and 7 weeks in age. Transgene copy numbers were determined by comparison of blot hybridizations of restriction endonuclease-digested DNA isolated from tails with known standards. For quantitative Southern analyses, autoradiograms were scanned densitometrically, using various exposures to optimize for differing signals. Some blots were analyzed also by surface emission scanning using the Betascope 603 blot analyzer (Betagen Corporation, Waltham, Massachusetts|. Transgene copy numbers in the founder line mice analyzed were determined in three different tissues from each mouse. No disagreements were observed among these values.

\section{$C A T, A D A$, and protein determinations}

Supernatants from tissue homogenates were prepared as described by Mercola et al. (1985) and diluted as necessary (up to $1: 200$ ) in buffer that contained $10 \mathrm{mg} / \mathrm{ml}$ bovine serum al bumin, incubated at $63^{\circ} \mathrm{C}$ for $15 \mathrm{~min}$, cooled at room temperature, and assayed at $37^{\circ} \mathrm{C}$ from 0.5 to $60 \mathrm{~min}$ so as to obtain linear initial rates of CAT activity. Acetylated products were quantitated by scintillation spectrometry in EcoLume (ICN Radiochemicals, Irvine, California). When individual extracts were reassayed, CAT specific activity values varied by $20 \%$ or less from the values obtained previously. When extracts from identical tissues of siblings within a given lineage were compared, CAT specific activity values differed by less than $50 \%$. This type of analysis, however, was not performed in a systematic fashion or for the majority of the transgenic lines. ADA activity was measured, as described previously /Wiginton et al. 1981). Protein assays were performed on unheated portions of extracts using the Bradford reagent system (Bio-Rad). 


\section{Quantitative determination of CAT and ADA $\mathrm{mRNA}$}

RNA was isolated from tissues according to Chomczynski and Sacchi (1987). For CAT mRNA quantitation, a vector was constructed that contained the 550-bp HindIII to Ncol /CAT-coding region) fragment of pSVO-CAT inserted via blunt ligation into the SmaI site of the pGEM3Z transcription vector. For mouse ADA mRNA analysis, a vector was constructed that contained a 997-bp NcoI to HindIII fragment from the mouse cDNA clone pADA5-29 (Yeung et al. 1985) that was inserted into the pBS transcription vector (Stratagene Cloning Systems, Inc. La Jolla, California). RNA transcripts were generated from vectors linearized at each end of the insert and purified from agarose gels. Antisense probes were made per manufacturers recommendations, except that $\left[\alpha^{-32} \mathrm{P} \mid \mathrm{CTP}\right.$ was used at a final CTP concentration of $20 \mu \mathrm{M}(50 \mu \mathrm{Ci} / 0.4 \mathrm{nM})$. Unlabeled sense-strand RNAs, used as internal quantitation standards, were made in large quantity, purified as above, and quantitated spectrophotometrically. Hybridizations were performed as described by Meyers et al. (1985) except that hybridizations were performed at $53^{\circ} \mathrm{C}$ for $15 \mathrm{hr}$ in $15 \mu \mathrm{l}$ of buffer that contained $400,000 \mathrm{cpm}$ of antisense probe, $20 \mu \mathrm{g}$ of either cellular RNA or carrier tRNA and, for standard quantitations, $0-200 \mathrm{pg}$ of sense-strand RNA. Unhybridized RNA was digested by addition of $185 \mu \mathrm{l}$ of an icecold solution that contained $0.45 \mathrm{M} \mathrm{NaCl}, 0.1 \mathrm{M} \mathrm{LiCl}, 10 \mathrm{~mm}$ Tris- $\mathrm{HCl},(\mathrm{pH} 7.4), 1 \mathrm{mM}$ EDTA, and $4 \mu \mathrm{g} / \mathrm{ml}$ RNase A. Then the solution was incubated at $16^{\circ} \mathrm{C}$ for $30 \mathrm{~min}$, processed as described and, without denaturation, electrophoresed through a $3.8 \%$ polyacrylamide gel that contained $1 \times \mathrm{TBE}$. Autoradiograms were scanned densitometrically as above, and some dried gels and blots were analyzed also by surface emission scanning using the Betascope 603 blot analyzer (Betagen Corporation, Waltham, Massachusetts|. When independent quantitation analyses were performed on an individual RNA sample, the resulting values varied between 10 and $30 \%$. Because this was not done for all samples, the reported values are those obtained when all tissue from an individual was quantitated as a group.

\section{In situ hybridization}

Dissected tissues were imbedded in O.C.T. compound (Miles Laboratories), frozen, cut into sections $6 \mu \mathrm{m}$ in thick, fixed, acetylated, prehybridized, and hybridized as described (Hayashi et al. 1977; Harper et al. 1986) with a solution that contained $\alpha^{-35}$-labeled RNA that was anti-sense to CAT mRNA $110^{8}$ $\mathrm{cpm} / \mathrm{ml}, 10^{8} \mathrm{cpm} / \mu \mathrm{g}$ probel and processed as described. The slide was dehydrated using ethanol dipped in NTB2 nuclear tract emulsion (Eastman), exposed for 36-72 hr, developed in D19 (Eastman), counterstained with hematoxylin and eosin, and examined under bright- and dark-field microscopy.

\section{In situ histochemical stain for ADA activity}

Histochemical staining was performed essentially as described by Spencer et al. (1968), as modified by Knudsen et al. (1988), except that the tissues were not treated with fixative. Dissected tissues were imbedded in O.C.T. compound (Miles Laboratories), frozen, cut into sections $12-\mu \mathrm{m}$ thick, applied to microscope slides, allowed to air-dry briefly, and incubated with a solution containing adenosine, purine nucleoside phosphorylase, phosphate, xanthine oxidase, phenazine methosulfate, and nitro blue tetrazolium, as described (Knudsen et al. 1988). Some sections were pretreated with $1 \mu \mathrm{M}$ deoxycoformycin, a powerful inhibitor of ADA activity, in a phosphate-buffered saline solution for $20 \mathrm{~min}$ at $37^{\circ} \mathrm{C}$, prior to the addition of the chromogenic cocktail. Incubations with the cocktail were carried out for $\mathrm{l} \mathrm{hr}$ at room temperature.

\section{DNA transfection of cultured cells}

Human lymphoid cell lines were transfected with a modification of a DEAE-dextran protocol provided to us by Dr. Jeffrey Leiden (Gottesdiener et al. 1988). Briefly, $3.3 \times 10$ E6 asynchronously dividing, mid-log growth phase cells were washed in TS buffer [TS buffer contains $0.14 \mathrm{M} \mathrm{NaCl}, 5.1 \mathrm{mM}$ $\mathrm{KCl}, 0.37 \mathrm{mM} \mathrm{Na}{ }_{2} \mathrm{HPO}_{4}, 24.8 \mathrm{mM}$ Tris- $\mathrm{HCl}(\mathrm{pH} 7.4$ ), with freshly added $1 \mathrm{mM} \mathrm{MgCl}_{2}$ and $0.87 \mathrm{mM} \mathrm{CaCl} l_{2}$, and resuspended in $0.33 \mathrm{ml}$ of transfection solution that contained DNA and DEAE-dextran (Sigma, m.w. 500,000). To prepare the transfection solution, $15 \mu \mathrm{g}$ of purified supercoiled plasmid DNA $[-2 \mathrm{mg} / \mathrm{ml}$ in buffer that contained $10 \mathrm{mM}$ Tris- $\mathrm{HCl}, 1$ mM EDTA $\{\mathrm{pH} 7.4)\}$ was stirred into $0.31 \mathrm{ml}$ of TS buffer, to which $17 \mu \mathrm{l}$ of $10 \mathrm{mg} / \mathrm{ml}$ DEAE-dextran was added, and allowed to incubate for $20 \mathrm{~min}$ at $25^{\circ} \mathrm{C}$. Cells were incubated in transfection solution for $15 \mathrm{~min}$ at room temperature, mixed with $3.3 \mathrm{ml}$ of RPMI that contained $5 \%$ fetal calf serum and 100 $\mu \mathrm{M}$ freshly prepared chloroquine, incubated at $37^{\circ} \mathrm{C}$ for $30 \mathrm{~min}$ washed and cultured in $10 \mathrm{ml}$ of growth medium that contained penicillin and streptomycin, and harvested at $42 \mathrm{hr}$.

\section{DNase I hypersensitivity}

Nuclei were prepared from tissues of 5- to 6-week-old ADA CAT $4 / 12$ transgenic mice, the normal thymus of a human child (snap-frozen during an incidental surgical procedure), and from a variety of human cell lines. Tissues were disrupted by means of a Pyrex tissue grinder, and cultured human cells via Dounce homogenization, in polyamine buffers modified from that of Hewish and Burgoyne (1973). The use of the polyamine buffer was critical in that DNA purified from nuclei prepared in the buffers that contained $\mathrm{Ca}^{2+}$ exhibited substantial cleavage at the typical hypersensitive sites even in the absence of added DNase I. The polyamine buffer contained $0.34 \mathrm{M}$ sucrose, 53 $\mathrm{mM} \mathrm{KCl}, 13 \mathrm{mM} \mathrm{NaCl}, 2 \mathrm{~mm}$ EDTA, $0.5 \mathrm{~mm}$ EGTA, $0.13 \mathrm{~mm}$ spermine, $0.5 \mathrm{mM}$ spermidine, $14 \mathrm{mM}$ freshly prepared 2 -mercaptoethanol, $0.1 \%$ Triton X-100, $13 \mathrm{~mm}$ Tris- $\mathrm{HCl}(\mathrm{pH} 7.4)$, and $1 \mathrm{mM}$ freshly prepared PMSF. With the above buffer, nuclei from cultured cells underwent nucleolysis. We found that this could be avoided by the addition of $3 \mathrm{mM} \mathrm{MgCl}_{2}$ to the polyamine buffer. Tissue homogenates were passed through $110-\mu \mathrm{m}$ polyethelene mesh (Spectrum Medical Industries, Los Angeles, California) with the aid of gentle suction. Nuclei were prepared from the homogenates and centrifuged at $2400 \mathrm{~g}$ for 30 min over a cushion of $1.2 \mathrm{M}$ sucrose in polyamine buffer. The nuclear pellet was washed twice in polyamine buffer without sucrose and detergent and resuspended in a DNase I digestion buffer that contained $60 \mathrm{mM} \mathrm{KCl}, 5 \mathrm{mM} \mathrm{MgCl}_{2}, 0.1 \mathrm{mM}$ EGTA, 0.5 mM DTT, $5 \%$ glycerol, and $15 \mathrm{~mm}$ Tris- $\mathrm{HCl}|\mathrm{pH} 7.5|$. Nuclei were suspended at a concentration of $1.25 \times 10^{7}$ to $3.5 \times 10^{7}$ nuclei/ml, and gentle DNase I digestions were carried out in a volume of $0.2 \mathrm{ml}$ with 7 units of DNase I (Boehringer-Mannheim) at $30^{\circ} \mathrm{C}$ for $1,2.5,5$, and $10 \mathrm{~min}$. Zero time points were not subjected to DNase I. DNA was prepared from nuclei treated or untreated with DNase I by the addition of an equal volume of a buffer that contained $0.6 \mathrm{M} \mathrm{NaCl}, 20 \mathrm{~mm}$ EDTA, 20 $\mathrm{mM}$ Tris- $\mathrm{HCl}\langle\mathrm{pH} 7.5\rangle$, and $0.5 \%$ SDS. The nuclear lysates were digested with $40 \mu \mathrm{g} / \mathrm{ml}$ of heat-treated RNase A for $2 \mathrm{hr}$ at $50^{\circ} \mathrm{C}$ followed by $300 \mu \mathrm{g} / \mathrm{ml}$ of proteinase $\mathrm{K}$ overnight at $37^{\circ} \mathrm{C}$. DNA was purified by phenol extraction and ethanol precipitation and quantitated spectrophotometrically. DNAs were digested with restriction endonucleases, electrophoresed through agarose gels, blot-transferred to Nytran (Schliecher \& Schuell), and hybridized to probes radiolabeled by means of random primers. The 5' probe was a 403-bp BamHI-Pst fragment, and the 3 ' probe a $280 \mathrm{bp}$ HindIII-HincII probe (Fig. 6). 
As a control, limited DNase I digestion of purified genomic DNA (CCRF-CEM) was also carried out using reduced amounts of DNase I. To do this, $500 \mu \mathrm{g}$ of DNA in $0.5 \mathrm{ml}$ of DNase I digestion buffer (above) was treated with $1.7 \mathrm{U} / \mathrm{ml}$ or $0.87 \mathrm{U} / \mathrm{ml}$ DNase I for 0-10 min, and analyzed, using HindIII and the 3' probe described in Figure 5. These analyses failed to detect the presence of DNase I-hypersensitive sites (results not shown).

\section{Acknowledgments}

We thank Dr. J. Christopher States for valuable suggestions in the early stages of this work, Kathy Saalfeld and Beatrice Kiser for assistance with in situ procedures, Dr. Jeffrey Leiden for a reproducible transfection method, Satbir Kaur and Drs. Brian Keye and Beverly Connelly for assistance with mouse work, and Drs. Roger Ganschow, Donal Luse, Ian Cartwright, Cori Gorman, and Sally Camper for valuable discussions and Jim DeBrosse for help with the manuscript. pADA5-29 was a generous gift of Dr. Rodney Kellems. This work was funded by grant HD-19919 from the National Institutes of Health (NIH). R.S. is supported by Molecular and Cellular Training grant (NIH) HL07527. B.A. is the recipient of a National Research Service Award (GM1 19828).

\section{References}

Adams, A. and R.A. Harkness. 1976. Adenosine deaminase activity in thymus and other human tissues. Clin. Exp. Immunol. 26: $647-649$.

Adkins, B., C. Mueller, C.Y. Okada, R.A. Reichert, I.L. Weissman, and G.J. Spangrude. 1987. Early events in T-cell maturation. Ann. Rev. Immunol. 5: 325-365.

Akeson, A.L., D.A. Wiginton, J.C. States, C.M. Perme, M.R. Dusing, and J.J. Hutton. 1987. Mutations in the human adenosine deaminase gene that affect protein structure and RNA splicing. Proc. Natl. Acad. Sci. 84: 5947-5951

Anderson, W.F. 1984. Prospects for human gene therapy. Science 226: 401-409.

Banerii, T.L., L. Olson, and W. Schaffner. 1983. A lymphocyte specific enhancer is located downstream of the joining region of immunoglobulin heavy chain genes. Cell 33: 729_ 740.

Bornstein, P., J. McKay, D.J. Liska, S. Apone, and S. Devarayalu. 1988. Interactions between the promoter and first intron are involved in transcriptional control of alphal(I) collagen gene expression. Mol. Cell. Biol. 8: 4851-4857.

Borzy, M.S., H. Schulte-Wissermann, E. Gilbert, S.D. Horowitz, J. Pellet, and R. Hong. 1979. Thymic morphology in immunodeficiency diseases: Results of thymic biopsies. Clin. Immunol. Immunopathol. 12: 31-51.

Brady, T.G. and C.I. O'Donovan. 1965. A study of the tissue distribution of adenosine deaminase in six mammal species. Comp. Biochem. Physiol. 14: 101-120.

Brinster, R.L., J.M. Allen, R.R. Behringer, R.E. Gelinas, and R.D. Palmiter. 1988. Introns increase transcriptional efficiency in transgenic mice. Proc. Natl. Acad. Sci. 85: 836-840.

Carrera, C.J. and D.A. Carson. 1987. Enzyme deficiencies associated with immunological disorders. In The molecular basis of blood diseases, led. G. Stamatoyannopoulos, A. Neinhuis, P. Leder, and P.W. Majerus), pp. 407-449. W.B. Saunders, Philadelphia, Pennsylvania.

Chechik, B., R. Baumal, and S. Sengupta. 1983. Localization and identity of adenosine deaminase-positive cells in tissues of the young rat and calf. Histochem. J. 15: 373-387.

Chechik, B., W.P. Schrader, and J. Minowada. 1981. An immunomorphologic study of the distribution of adenosine de- aminase distribution in human thymus tissue, normal thymocytes, and hematopoietic cell lines. I. Immunol. 126: $1003-1007$.

Chomczynski, P. and N. Sacchi. 1987. Single-step method of RNA isolation by acid guanidinium thiocyanate-phenol chloroform extraction. Anal. Biochem. 162: 156-159.

DeNegris, S.J., M. Hamosh, D.K. Kaskebar, T.C. Lee, and P. Hamosh. 1988. Lingual and gastric lipases: Species differences in the origin of prepancreatic digestive lipases and in the localization of gastic lipase. Biochim. Biophys. Acta. 959: 38-45.

Dzierzak, E.A., T. Papayannopoulou, and R.C. Mulligan. 1988. Lineage-specific expression of a human $\beta$-globin gene in murine bone marrow transplant recipients reconstituted with retrovirus-transduced stem cells. Nature 331: 35-41.

Elgin, S.C.R. 1988. The formation and function of DNase I hypersensitive sites in the process of gene activation. $/$. Biol. Chem. 263: 19259-19262.

Geyer, P.K. and V.G. Corces. 1987. Separate regulatory elements are responsible for the complex pattern of tissue-specific and developmental transcription of the yellow locus in Drosophila melanogaster. Genes Dev. 1: 996-1004.

Giblett, E.R., J.E. Anderson, F. Cohen, B. Pollara, and H.J. Meuwissen. 1972. Adenosine deaminase deficiency in two patients with severely impaired cellular immunity. Lancet 2: $1067-1069$.

Gillies, S., S. Morrison, V. Oi, and S. Tonegawa. 1983. A tissuespecific transcription enhancer is located in the major intron of a rearranged immunoglobulin heavy chain gene. Cell 33: $717-728$.

Gordon, J.W., P.G. Chesa, H. Nishimura, W.J. Rettig, J.E. Maccari, T. Endo, E. Seravalli, T. Seki, and I. Silver. 1987. Regulation of Thy-1 gene expression in transgenic mice. Cell 50: $445-452$.

Gorman, C., L.F. Moffat, and B.H. Howard. 1982. Recombinant genes which express chloramphenicol acetyltransferase in mammalian cells. Mol. Cell. Biol. 2: 1044-1051.

Gosseye, S., N. Diebold, C. Griscelli, and C. Nezelof. 1983. Severe combined immunodeficiency disease: A pathological analysis of 26 cases. Clin. Immunol. Immunopathol. 29: $58-77$.

Gottesdiener, K.M., B.A. Karpinski, T. Lindsten, I.L. Strominger, N.H. Jones, C.B. Thompson, and J.M. Leiden. 1988. Isolation and structural characterization of the human 4F2 heavy-chain gene, an inducible gene involved in T-lymphocyte activation. Mol. Cell. Biol. 8: 3809-3819.

Gross, D.S. and W.T. Garrard. 1988. Nuclease hypersensitive sites in chromatin. Annu. Rev. Biochem. 57: 159-197.

Grosveld, F., G.B. van Assendelft, D.R. Greaves, and G. Kollias. 1987. Position-independent, high-level expression of the human $\beta$-globin gene in transgenic mice. Cell 51: 975-985.

Harper, M., L. Masselle, R. Gallo, and F. Wong-Staal. 1986. Detection of lymphocytes expressing human T-lymphotropic virus type III in lymph nodes and peripheral blood from in fected individuals by in situ hybridization. Proc. Natl. Acad. Sci. 83: $772-776$

Hayashi, S., I.C. Gilliam, A.D. Delaney, and G.M. Tener. 1977. Acetylation of chromosome squashes of Drosophila melanogaster decreases the background of autoradiographs from hybridization with $125 \mathrm{I}$ labeled RNA probes. I. Histochem. Cytochem. 26: 677-679.

Hayashi, S., K. Goto, T.S. Okada, and H. Kondoh. 1987. Lensspecific enhancer in the third intron regulates expression of the chicken d1-crystallin gene. Genes Dev. 1: 818-828.

Hewish, D.R. and L.A. Burgoyne. 1973. Chromatin substructure. The digestion of chromatin DNA at regularly spaced 
sites by a nuclear deoxyribonuclease. Biochem. Biophys. Res. Comm. 52: 504-510.

Hirschhorn, R. and A. Ellenbogen. 1986. Genetic heterogeneity in partial ADA deficiency: II: Identification of at least three additional variants in five new patients. Am. I. Hum. Genet. 38: $13-25$.

Hirshhorn, R., F. Martinuik, and F.S. Rosen. 1978. Adenosine deaminase activity in normal tissues and tissues from a child with severe combined immunodeficiency and adenosine deaminase deficiency. Clin. Immun. Immunopath. 9: $287-292$.

Hogan, B., F. Constantini, and E. Lacy. 1986. Manipulating the mouse embryo Cold Spring Harbor Laboratory, Cold Spring Harbor, New York.

Karpinski, B.A., L. Yang, P. Cacheris, G.D. Morle, and J.M. Leiden. 1989. The first intron of the 4F2 heavy chain gene contains a transcriptional enhancer element that binds multiple nuclear proteins. Mol. Cell. Biol. 9: 2588-2597.

Kelsey, G.D., S. Povey, A.E. Bygrave, and R.H. Lovell-Badge. 1987. Species- and tissue-specific expression of human $\alpha_{1}$ antitrypsin in transgenic mice. Genes Dev. 1: 161-171.

Kizaki, H., S. Habu, F. Ohsaka, and T. Sakurada. 1983. Purine nucleoside metabolizing enzyme activities at different stages of mouse thymocyte differentiation and maturation. Cell. Immunol. 82: 343-351.

Knudsen, T.B., J.D. Green, M.J. Airhart, H.R. Higley, J.M. Chinsky, and R.D. Kellems. 1988. Developmental expression of adenosine deaminase in placental tissues of the early postimplantation mouse embryo and uterine stroma. Biol. Repro. 39: 937-951.

Lattier, D.L., J.C. States, J.J. Hutton, and D.A. Wiginton. 1989. Cell type specific transcriptional regulation of the human adenosine deaminase gene. Nucleic Acids Res. 17: 10611076.

Lee, P.C. 1973. Developmental changes of adenosine deaminase, xanthine oxidase, and uricase in mouse tissues. Dev. Biol. 31: 227-233.

Ma, D.D.F., T.A. Sylwestrowicz, S. Granger, M. Massaia, R. Franks, G. Janossy, and A.V. Hoffbrand. 1982. Distribution of terminal deoxynucleotidyl transferase and purine degradative and synthetic enzymes in subpopulations of human thymocytes. I. Immunol. 129: 1430-1435.

Mcphee, D., J. Pye, and K. Shortman. 1979. The differentiation of T-lymphocytes. V. Evidence for intrathymic death of most thymocytes. Thymus 1: 151 .

Mercola, M., J. Goverman, and K. Calame. 1985. Immunoglobulin heavy-chain enhancer requires one or more tissue-specific factors. Science 227: 266-270.

Meyers, R., Z. Larin, and T. Maniatis. 1985. Detection of single base substitutions by ribonuclease cleavage at mismatches in RNA : DNA duplexes. Science 230: 1242-1246.

Palmiter, R. D. and R.L. Brinster. 1986. Germ line transformation of mice. Annu. Rev. Genet. 20: 465-499.

Ryan, T.M., R.R. Behringer, N.C. Martin, T.M. Townes, R.D. Palmiter, and R. L. Brinster. 1989. A Single erythroid-specific DNase I super-hypersensitive site activates high levels of human $\beta$-globin gene expression in transgenic mice. Genes Dev. 3: 314-324.

Spencer, N., D.H. Hopkinson, and H. Harris. 1968. Adenosine deaminase polymorphism in man. Annu. Hum. Genet. 32: 9-15.

Tischfield, J.A., R.P. Creagan, E.A. Nichols, and F.H Ruddle. 1974. Assignment of a gene for adenosine deamianase to chromosome 20. Hum. Hered. 24: 1-11.

Valerio, D., M.G.C. Duyvesteyn, B.M.M. Dekker, G. Weeda, T. Berkvens, L. Van der Voorn, Van Ormondt, and A.J. Van der
Eb. 1985. Adenosine deaminase: Characterization and expression of a gene with a remarkable promoter. $E M B O I$. 4: 437-443.

Van der Weyden, M.B. and W.N. Kelley. 1976. Human adenosine deaminase. Distibution and Properties. I. Biol. Chem. 251: $5448-5456$.

Wiginton, D.A., M.S. Coleman, and J.J. Hutton. 1981. Purification, characterization, and radioimmunoassay of adenosine deaminase from human leukemic granulocytes. Biochem. $I$. 195: 389-397.

Wiginton, D.A., D.J. Kaplan, J.C. States, A.L. Akeson, C.M Perme, I.J. Bilyk, A.J. Vaughn, D.J. Lattier, and J.J. Hutton. 1986. Complete sequence and structure of the gene for human adenosine deaminase. Biochemistry 25: 8234-8244.

Wu, C. 1980 . The $5^{\prime}$ ends of Drosophila heat shock genes in chromatin are hypersensitive to DNase I. Nature 309: 229234.

Wu, C. 1984. Activating protein factor binds in vitro to upstream control sequences in heat-shock gene chromatin. Nature 311: $81-84$

Yeung, C.-Y., D. Ingolia, D.B. Roth, C. Schoemaker, M.R. AlUbaidi, J.Y. Yen, C. Ching, C. Bobonis, R.J. Kaufman, and R.J. Kellems. 1985. Identification of functional murine adenosine deaminase clones by complementation in E. Coli. J. Biol. Chem. 260: 10299-10307. 


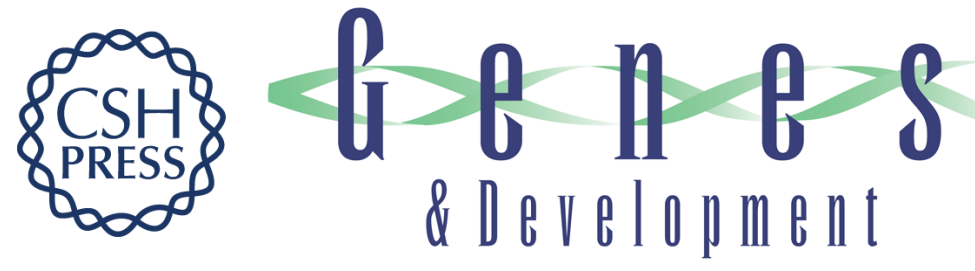

\section{Evidence for a complex regulatory array in the first intron of the human adenosine deaminase gene.}

B Aronow, D Lattier, R Silbiger, et al.

Genes Dev. 1989, 3:

Access the most recent version at doi:10.1101/gad.3.9.1384

References This article cites 51 articles, 20 of which can be accessed free at:

http://genesdev.cshlp.org/content/3/9/1384.full.html\#ref-list-1

License

Email Alerting

Service

Receive free email alerts when new articles cite this article - sign up in the box at the top right corner of the article or click here.

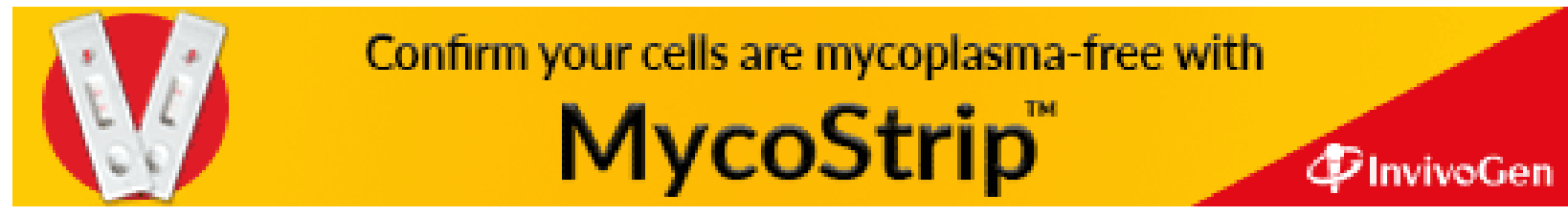

